Article

\title{
Between Love, Renunciation, and Compassionate Heroism: Reading Sanskrit Buddhist Literature through the Prism of Disgust
}

\author{
Shenghai Li \\ Institute for the Preservation and Conservation of Ancient Chinese Books, Fudan University, \\ Shanghai 200433, China; shenghaili@gmail.com
}

Received: 15 July 2020; Accepted: 10 September 2020; Published: 15 September 2020

check for updates

\begin{abstract}
Disgust occupies a particular space in Buddhism where repulsive aspects of the human body are visualized and reflected upon in contemplative practices. The Indian tradition of aesthetics also recognizes disgust as one of the basic human emotions that can be transformed into an aestheticized form, which is experienced when one enjoys drama and poetry. Buddhist literature offers a particularly fertile ground for both religious and literary ideas to manifest, unravel, and entangle in a narrative setting. It is in this context that we find elements of disgust being incorporated into two types of Buddhist narrative: (1) discouragement with worldly objects and renunciation, and (2) courageous acts of self-sacrifice. Vidyākara's anthology of Sanskrit poetry (Subhāșitaratnakoșa) and the poetics section of Sa skya Pandita's introduction to the Indian systems of cultural knowledge (Mkhas pa rnams 'jug pa'i sgo) offer two rare examples of Buddhist engagement with aesthetics of emotions. In addition to some developed views of literary critics, these two Buddhist writers are relied on in this study to provide perspectives on how Buddhists themselves in the final phase of Indian Buddhism might have read Buddhist literature in light of what they learned from the theory of aesthetics.
\end{abstract}

Keywords: disgust; Buddhist literature; Indian aesthetics; rasa; Subhāșitaratnakoṣa; Buddhacarita; Nāgānanda; Sa skya Paṇ̣̂ita

\section{Introduction}

Disgust has a complex history in Buddhist thought that is yet to be fully written. The core of the Buddhist discourses surrounding the idea of disgust appears to be a contemplative practice in which repulsive aspects of the human body are intentionally visualized and cultivated. While scriptural and scholastic Buddhist sources tend to present the subject in the discussions of this specific Buddhist meditation, it also becomes available as a theme that can be applied to many other contexts. The repulsive also manifests in different forms in biographies, literature, arts, tantrism, and other fields of Buddhist cultures. A comparison can be fruitfully made between disgust in Buddhism and the grotesque in the European and American cultures: both are aesthetic terms that encompass a host of connotations as well as historical and regional variations. ${ }^{1}$ A particular case of the grotesque, one that involves the human body in its abnormal states, is a typical topic that invokes the response of disgust in the Buddhist tradition.

Some of the noteworthy studies of disgust in Buddhism have approached the subject from a feminist perspective. The presentation of the female body as repulsive as a way of helping male

1 For a short overview of the grotesque with recommended readings, see (Graulund 2019). As noted in this short survey, the grotesque has drawn attention from prominent modern theorists such as Michel Foucault, Julia Kristeva, and Mikhail Bakhtin. A short overview of European and American theories of disgust is available in (Langenberg 2017, pp. 79-81). 
Buddhist ascetics to turn their minds away from sexuality and to advance in their religious practices, for instance, has been examined by Liz Wilson on the basis of Indian Buddhist hagiographies. ${ }^{2}$ Amy Paris Langenberg also offers feminist reading of related Buddhist texts where disgust is used as a lens through which to study childbirth in Buddhist traditions. ${ }^{3}$ One particularly innovative aspects of her approach is the light that her work sheds on the intersection between the Buddhist representations of the repulsive and Sanskrit poetics and aesthetics. ${ }^{4}$ Disgust (jugups $\left.\bar{a}\right)$, after all, is reckoned in the Sanskrit literary theories among recognized stable emotional states (sthāyibhāva)—emotions that we experience in our everyday experience- that are transformed by the artistic process into aestheticized emotions ( $r a s a)$-in this particular case, the loathsome (bibhatsa $)$ - which are then consumed and appreciated in an aesthetic experience. The theory of aestheticized emotions or sentiments ( $r a s a$ ) harks back to the origin of Sanskrit literary theory, and its relevance could not have been lost on many Buddhist poets and readers when the theme of repulsiveness is encountered.

We will examine instances of Buddhist literature from South Asia while keeping Sanskrit literary theory in mind. For now, however, an anthology of Sanskrit poetry, Subhāsitaratnakoṣa, can illustrate for us the same point albeit from the reverse route. In this particular case, we find a Buddhist connoisseur reading general Sanskrit poetry rather than a poet applying Sanskrit literary theory to the writing of Buddhist literature. The anthologist responsible for compiling the collection in question has been identified as Vidyākara, a Buddhist scholar from Bengal in the latter half of the eleventh century, who selected Sanskrit poems from a collection thought to be housed in a Buddhist monastic library. ${ }^{5}$ Vidyākara's Buddhist affiliation manifests overtly in the anthology only in the three initial sections of the work, where poems honoring the Buddha and the bodhisattvas Lokeśvara and Mañjughoṣa are assembled. Other parts of the work, however, reflect a larger body of Sanskrit poetry on a wide variety of topics without privileging verses or even authors connected with Buddhism.

It is in the sections with no ostensible Buddhist connection that we find the exhibition of the anthologist's religious identity in certain choices that he makes. A case in point is the section of the collection named the "Cremation Ground" (śmaśāna), the inclusion of which can be justified alone by virtue of the fact that horrific sights from that unfriendly environment is typically chosen to invoke the rasa of loathsome. ${ }^{6}$ However, this is also a site of interest to Buddhist texts when they turn to the topic of repulsiveness, as we will see shortly. The convergence of interest explains why Vidyākara might have savored these verses because they are fashioned in the hands of great poets, whose skills are put to work to embellish a subject of double significance. Consider, for example, a verse extracted from Bhavabhūti's drama Mālatīmādhava:

A wretched ghost first tears the skin again and again, he then consumes the large and swollen pieces of flesh, terrifying and putrid, in such parts as shoulders, buttocks, and the back;

then, drawing out the tendons, entrails, and eyes and baring his teeth,

from the corpse on his lap he eats with no hurry

the remnants even from the joints and small cavities. ${ }^{7}$

\footnotetext{
(Wilson 1996).

3 For her methodological considerations of applying feminist criticism to premodern Buddhist texts, see (Langenberg 2017, pp. 12-17).

$4 \quad$ See chapter 3, esp. ibid., pp. 77-87.

5 (Kosambi and Gokhale 1957, pp. xxxi-xxxix; Ingalls 1965, p. 30). More recent comments on the anthologist and the work can be found in (Martin 2014, pp. 593-95).

6 The śmaśāna section is edited in Kosambi and Gokhale, Subhāsitaratnakoṣa, pp. 263-66 and translated in Ingalls, Anthology of Sanskrit Poetry, pp. 398-401.

7 Subhāșitaratnakoṣa 1530 and Mālatīmādhava 5.16. Kosambi and Gokhale, Subhāṣitaratnakoṣa, 264, with emendation in Ingalls Anthology of Sanskrit Poetry, 464: utkrtyokrtya krttim prathamam atha prthücchophabhūyāmssi māmsāny
} 
In literature, creatures from the unseen world, along with jackals and vultures, search cremation grounds and cemeteries and take possession of corpses left unburnt or putrefied. The poem sampled here portrays the gruesome proceedings of a ghost's feast at the cemetery. Phonologically, the verse features the alliteration (anuprāsa) of harsh-sounding consonants, while the use of long compounds contributes to an august (ojas) poetic quality (guna). ${ }^{8}$ Both of these factors add musically to the representation of repulsiveness. Vidyākara's cemetery section recovers among other things a genealogy of Sanskrit playwrights on the rasa of loathsome: from Harṣa to Bhavabhūti and Kṣemīsvara, all of whom are presumed to be based in the intellectual center of Kannauj. The interest in unpleasurable sentiments shared by Bhavabhūti and Kṣemīśvara has already been noted, and we will have more to say about Harșa in the context of his Buddhist drama Nāgānanda. ${ }^{9}$

The present study examines disgust through its representation in Sanskrit Buddhist literature. Buddhist literary texts from South Asia both follow the subcontinent's literary conventions and are informed by the Buddhist world view. Both traditions therefore need to be taken into account even if their values could be in tension with each other at times. In our particular case, the roles that disgust plays in doctrinal texts differ from those that it takes on in literary works. In the former, teachings on repulsiveness are assigned a place in the religious path; in the latter, it often assumes a role in the narratives that portray human lives. Special attention, therefore, will have to be given to the function of disgust in narrative structures. Before turning to the literary texts, however, it will be useful to examine Buddhist scriptures to provide the background information on the repulsive meditation. The available primary sources on this topic is vast. Since the main subject of this study is disgust in narrative texts and poetry rather than in scriptures, a number of sütra sources and scholastic treatises will be used here just to contextualize the examination of literary texts. It is worth noting that being comprehensive treatments of the contents of scriptures, scholastic works such as the Visuddhimagga, Abhidharmakośabhāsya, and Yogāāārabhūmi offer systematic analyses of the contemplation on the repulsive. We will look at (1) two major forms of the repulsiveness meditation: contemplations on the impurities in the living body and in corpses; (2) the place of the repulsiveness meditation in the larger program of Buddhist meditation; and (3) ways in which this meditation relates thematically to the representation of the repulsive in literary texts.

\section{Results}

\subsection{Two Spaces for Repulsiveness: Buddhist Meditation and Literary Representation}

The contemplation on the repulsive (aśubhabhāvanā) is one of the most common subjects of meditation described in classical Buddhist texts. A list of more than thirty foul parts of the body or a series of nine or ten stages of a corpse's decomposition are often enumerated as specific objects that meditators focus on when cultivating such a meditation. The name aśubha along with its various Asian linguistic forms and translations, such as the Pali asubha, Chinese bujing (不淨), and Tibetan mi sdug $p a$, carry a range of connotations that include repulsive, unpleasant, disagreeable, ugly, impure, inauspicious, or simply bad. Descriptions of this contemplative practice show that the cultivation of something provoking disgust is an essential part of it.

angasphikphrșthapindādyavayavasulabhāny ugrapūtīni jagdhvā/ āttasnāyvantranetrah prakațitadaśanah pretaranikah karaìkād à்kasthād asthisamsthasthaputagatam api kravyam avyagram atti//. Cf. Ingalls' translation in ibid., p. $39 \dot{9}$.

8 The use of similar sound effects in the verses evoking the loathsome written by Ksemīsvara, who is also featured in the same section of Vidyākara's anthology, is discussed in (Sathaye 2010, pp. 366-67). The Sanskrit literary theorist Dandin discusses alliteration in Kāoyadarśa 1.55-60 (where harsh combinations are illustrated and discussed in 1.59-60), and he presents the quality august in Kāoyadarśa 1.80-84. See (Thakur and Jha 1957, pp. 37-40, 49-51; Dimitrov 2002, pp. 180-83, 192-95).

9 The three verses from Kșemīśvara's Candakauśika that are anthologized in the Subhāsitaratnakoșa (1537, 1538, and 1539) have been discussed by Sathaye along with a few other stanzas from the drama in his "The Production of Unpleasurable Rasas," pp. 365-71. Sathaye notes the affinity between Bhavabhūti and Kṣemīśvara on the unpleasurable rasas in pp. 364-65, 366. 
Buddhaghosa makes this point clearly in a fifth-century Pali manual of Buddhist scholarship and practices, the Visuddhimagga. His treatment of this meditation presents ten manners of putrefaction, which he names as "bloated," "livid," "festering," "cut up," "gnawed," "scattered," "hacked and scattered," "bleeding," "worm-infested," and "skeleton," to be taken up by a meditator as objects of meditation. ${ }^{10}$ He clarifies that these terms refer to a corpse in these states. The idea of disgust is present in the explanation of the nomenclature, as Buddhaghosa writes that a swollen corpse or the "bloated," for instance, is referred by that name "because the bloated is bad, being repulsive."11 More importantly, the process of cultivation must capture the repugnant feature of the object, as the meditator repeats to oneself internally such phrases as the "repulsiveness of the bloated."12

The presentation of the contemplation on the repulsive in the Visuddhimagga emphasizes the stages of the body's decomposition. Its discussion is comprehensive, having summarized materials from scriptural sources such as the Kāyagatāsatisutta of the Majjhimanikāya. ${ }^{13}$ The Kāyagatāsatisutta, which provides instructions on the cultivation of the mindfulness of the body, also gives a list of impure parts of a living body, which a Buddhist ascetic may survey in the repulsiveness meditation.

Again, bhikkhus, a bhikkhu reviews the same body up from the soles of the feet and down from the top of the hair, bounded by skin, as full of many kinds of impurities thus: "In this body there are head-hairs, body-hairs, nails, teeth, skin, flesh, sinews, bones, bone-marrow, kidney, heart, liver, diaphragm, spleen, lungs, intestines, mesentery, contents of the stomach, feces, bile, phlegm, pus, blood, sweat, fat, tears, greese, spittle, snot, oil of the joints, and urine." 14

The model of reflecting on the repulsive parts of the human body, documented in this scriptural source of early Buddhism, informs an episode in the life of the Buddha narrated in the Sanskrit text of the Lalitavistarasütra. The latter text, which most likely existed in the second century CE, contains the following versified lines:

Grown in the field of karma, born from the water of craving, formed through the false notion of personality,

wet with tear, sweat, and phlegm and distorted by urine, filled with drops of blood,

[the body] is full of pus and fat from the belly, cerebral fluids, and filth as well.

Every impure thing, with different kinds of foul smell, indeed constantly flows.

[It is] disfigured with bones, teeth, and hairs both on the head and body, covered with skin, hairy,

hoarding inside spleen, liver, mucus, bile, and saliva, [bodily components that are] weak,

like a mechanical device held together by marrow and ligaments and beautified by flesh,

full of various kinds of disease, mixed with grief, and beset by hunger and thirst. ${ }^{15}$

10 (Rhys Davids 1975, p. 178): uddhumātakam vinūlakam vipubbakam vicchidakam vikkhāyitakam vikkhittakam hatavikkhittakam lohitakam puluvakam atthikan ti. These terms are translated in (Ñānamoli 2010, p. 169).

11 (Rhys Davids 1975, p. 178): pațikūlattā vā kucchitạ̣ uddhumātam iti uddhumātakam. Cf. (Ñānamoli 2010, p. 169).

12 (Rhys Davids 1975, p. 186): üddhumātakapațikūlạ̣! uddhumātakapațikūlan! ti. See also ibid., pp. 190-93. (Ñānamoli 2010, pp. 176, 179-82).

13 (Chalmers 1994, pp. 91-92). For an English translation, see (Ñānamoli and Bodhi 2005, p. 952).

14 The English translations of Nānanamoli and Bodhi Bhikkhus are adopted here. See (Ñānamoli and Bodhi 2005, p. 951). (Chalmers 1994, p. 90): puna ca param bhikkhave bhikkhu imam eva kāyam uddham pādatalā adho kesamatthakā tacapariyantam püram nānappakārassa asucino paccavekkhati atthi imasmim kāye kesā lomā nakhā dantā taco mamsam nahāru ațthi ațthimiñjā vakkam hadayam yakanam kilomakam pihakam papphāsam antạ̣ antagunam udariyam karīsam pittaṃ semaham pub̈bo löhitam sedo medo assu vasā khelo singhānikā lasikā muttan ti.

15 (Lefmann 1977, p. 208): karmaksetraruham tusāsalilajam satkāyasamjñ̄īkrtam aśrusvedakaphārdramutravikrtam śonītabindvākulam/ vastīpūyavasāsamastakarasaih pürnam tathà kilviśaih nityaprasravitạn hy amedhyasakalam dürgandhanānāvidhaị// asthīdantasakeśaromavikrtam carmāurtạ̣ lomasam antahplīhajakrdvapoṣnarasanair ebhiś citam durbalai majjäsnāyunibaddhayantrasadŕśạn māmsena śobhīkrtam nänāoyādhiprakīrnasokakalilam kṣuttarșasampịditaṃ//. 
Back in the Visuddhimagga, Buddhaghosa's account describes at length how a Buddhist ascetic may visit a cemetery to observe corpses in the states enumerated above. In addition to cemeteries, in the context of describing "cut up" bodies as an object, he also mentions battlefields, robbers' forests, charnel grounds where kings have robbers cut up, and jungles where men's bodies are torn by lions and tigers as localities where meditators can find dismembered human bodies to study. ${ }^{16}$ During such trips, according to him, meditators open their eyes to look at the corpse a hundred or even a thousand times, before closing their eyes to contemplate, in a process where the experience in the real world must be internalized. ${ }^{17}$ The study trips surely help to achieve a high degree of vividness in the image being visualized. In the case of the meditation on the swollen body, for instance, the mark of a successful internalization, the so called "acquired sign," consists of an "unsightly, dreadful, frightful sight."18

While textual sources are clear that a response of disgust toward unsightly body images is an integral part of this contemplative practice, they also indicate that disgust itself is not the goal of the meditation. The contemplation on the repulsive, first of all, is one of the subjects that are recommended to meditators who have an unbalanced psychological makeup, for whom the prescribed meditation serves the purpose of controlling a dominant emotion and prevents it from distracting one from successful contemplative practices. According to one textual source from the early tradition, contemplations on the repulsive, love, dependent origination, classification of elements, and breathing are to be taken up by yogis whose personal traits are dominated by attachment, anger, confusion, arrogance, and discursive thoughts, respectively. ${ }^{19}$ The unpleasant features of the human body are therefore visualized for a specific purpose: to neutralize attachment that is the dominant emotion. When the predominance of attachment does not result in an unbalance, notes The Stage of the Disciples (Śrāvakabhūmi), meditators can simply choose whichever object as they please and apply themselves to it, if their behavioral habits are evenly distributed (samabhägacarita) or if their impurity is light (mandarajaska). ${ }^{20}$

Just what kind of attachment are we speaking of, if the contemplation on the repulsive functions as its remedy? The fifth-century Buddhist writer Vasubandhu mentions four kinds of attachment: those pertaining to color, shape, touch, and receiving service. The countermeasures for these four types of attachment are none other than the contemplation on several kinds of decomposed bodies we have seen earlier: bodies that are livid or discolored, gnawed and scattered bodies, worm-infested bodies or those filled with pus, and dead and motionless bodies. ${ }^{21}$ Here, we are surely dealing with concerns of

16 (Rhys Davids 1975, p. 190; Ñānamoli 2010, p. 179).

17 (Rhys Davids 1975, pp. 185-86): cakkhum unmīletvā oloketvā nimittam ganhitabbạ̣ satakkhattum sahassakkhattum pi unmīletvā oloketabbam nimmīletvā àvajjitabbam evaṃ punappunam karontassa uggahanimittam suggahitam hoti. (Ñānamoli 2010, p. 176).

18 (Rhys Davids 1975, p. 189): uggahanimittam virūpam bịbhaccham bheravadassanam hutvā upațthāti. (Ñānamoli 2010, p. 178). The acquired sign (uggahanimitta) is contrasted with the sign of semblance (patibhāganimitta), which does not fulfill the intended purpose.

19 The Śrāvakabhūmi, which dates back to at least the fourth century CE, cites this tradition from a sütra source. See (Shukla 1973, p. 198): revata bhikṣur yogī yogācāro rāgacarita eva sa na śubhālambane cittam upanibadhnāti/ evam anurūpe ālambane cittam upanibadhnāti dveșacarito vā punar maitryām mohacarito vā idam pratyayatāpratītyasamutpāde mānacarito dhātuprabhede/ sa ced revata sa bhikșur yogī yogācāro vitarkacarita èva ānāpānasmrtau cittam upanibadhnāti). The Chinese translation of Xuanzang in the Taishō edition of the Chinese Tripitaka is edited in Takakusu and Watanabe (1924-1932), hereafter T., in no. 1579 XXX 428a11-17: 謂彼比丘若唯有貪行。應於不淨緣安住於心。如是名為於相稱緣安住其心。若唯有瞋行。應於 慈壂安住其心。若唯有癡行。應於緣性緣起安住其心。若唯有慢行。應於界差別安住其心。若唯有尋思行。應於阿那波那 念安住其心。如是名為於相稱緣安住其心. For the Tibetan translation, see the Sde dge edition of the Tibetan Bstan 'gyur, no. 4036 in the catalog of (Ui et al. 1934), Sems tsam, vol. dzi 77a4-7. This sūtra source involves a conversation between the Buddha and his disciple Revata. The editor of the Sanskrit text, Shukla, notes (197n1), "This dialogue is not traced in the Pāli canons, the Mahāyāna Sūtras, the Prajñāpāramitās, and other canons of the Buddhists extant in Sanskrit and Pāli. It seems that this forms part of the Sanskrit Tripitaka of the Mahāsāṃghikas or of any other sect of the Buddhist order, whose canonical literature is not extant."

20 (Shukla 1973, p. 334): samabhāgacaritasya tu yatra priyārohitā tatra tena prayoktavyam kevalam cittasthitaye na tu caritaviśuddhaye/ yathā samabhāgacarita evam mandarajasko veditavyah/; T. 1579 XXX 446a2-5: 若等分行補特伽羅。隨所愛樂攀緣彼境勤修加行。 如是勤修唯令心住非淨其行。如等分行補特伽羅。薄塵行者當知亦爾.

21 (Pradhan 1967, p. 337): tatra punaś caturviddho rāgah varnarāgah saṃsthānarāga sparśarāga upacārarāgaś cal prathamasya pratipakṣena vin̄ilakādyākārālambanām aśubhām varjayanti dvitīyasya vikhāditakavikșiptālambanām tṛtìyasya vipatumakam pūyanibaddhāsthyālambanām caturthasya niśceștamrtakāyālambanām/. T. 1558 XXIX 117b22-28: 然貪差別略有四種。一顯 
the ascetic life where avoiding carnal desire is a matter of critical importance. Buddhaghosa, moreover, is very specific in his insistence that meditators must not choose a body of the opposite sex to observe, lest that attraction to even corpses could potentially compromise sexual abstinence. Discourses on female bodily foulness are nevertheless common in doctrinal works, which are often intended for the male audience; descriptions of the female body, including its beauty, moreover, figure conspicuously in Buddhist literary texts, as we will see later.

In addition to the idea that repugnant bodily images are reflected upon only to bring excessive and distractive level of desire under control, there is another reason why disgust is a means rather than an end. After an uncontrolled emotion is subdued and the issue of unbalance resolved, contemplation on the repulsive remains an optional topic of meditation open to any meditator. If the meditator so chooses, while the repulsive remains the object of cultivation, the meditator's mental state improves as higher degrees of proficiency are reached. There arises the experience of joy (piti), tranquility (passaddhi), bliss (sukha), concentration (samādhi), and single focus (ekaggatā), which are factors that accompany the achievement of the meditative state. ${ }^{22}$

There is another Buddhist context allowing the repulsive a role to play, where one typical setting is the selfless acts of the Buddha in a former lives when he sacrificed his body or limbs to save others or to fulfill their requests. In Mahāyāna Buddhism, such extraordinary acts are described as one of the Mahāyāna Buddhist practices, often as a part of the perfection of generosity (dānapāramitā). The Mahāyāna Vinayaviniścayasūtra, also known as the Upāliparipṛcchā, describes the following three kinds of generosity performed by advanced bodhisattvas: (1) Generosity: giving up kingship. (2) Great generosity: giving up one's wife, sons, and daughters. (3) Extreme generosity: giving away one's head, arms, legs, eyes, skin, and bones. ${ }^{23}$ While a sūtra text such as the Vinayaviniścaya might speak only in the abstract, the giving of the third type of gift in a narrative context sometimes unveils the repulsive side of the selfless act.

From this brief sketch of classical Pali and Sanskrit sources on repulsiveness, two key points relevant to Buddhist literature have emerged. First of all, in the context of meditation disgust induced by directing one's attention to the disagreeable functions as a non-climactic part of a larger trajectory, which ultimately leads to tranquility and peace. The course of meditation on the repulsive could serve as a Buddhist model for how disgust functions in narratives as well. Indeed, the problem is not unique to Buddhist literature alone, as there are unpleasurable emotional states-grief (śoka), anger (krodha), fear (bhaya), and disgust (jugupsā) — that are recognized by the Indian theoretical tradition and demonstrated in literature. ${ }^{24}$ For certain Indian writers like Kṣemīśvara, the unpleasurable rasas could even take the center stage in a literary work. In the revolutionary ninth-century theoretical work of Ānandavardhana, the appreciation of rasa is advocated as the overriding goal of poetry. Under that framework, one approach to the unpleasurable emotions, to avoid the problem of letting them dominate the story, is to treat them in such a way that they are "carefully subordinated to pleasurable ones." 25

色貪。二形色貪。三妙觸貪。四供奉貪。緣青瘀等修不淨觀治第一貪。緣彼食等修不淨觀治第二貪。緣蟲蛆等修不淨觀治 第三貪。緣屍不動修不淨觀治第四貪. Vasubandhu goes on to say that the meditation on the skeleton is a remedy for all four kinds of attachment. Cf. (Rhys Davids 1975, pp. 193-94; Ñānamoli 2010, p. 182) on specific desires that the meditation on each of the ten states of the decomposed body is meant to dispel.

22 (Rhys Davids 1975, pp. 189-90): pațiladdhavisesādhigamapaccayā pìti pītimanassa passaddhisambhavato passaddhinimittam sukham sukhitassa cittasamādhisambhavato sukhanimittā ekaggatā cā ti jhānangāni pātubhavanti. (Ñānamoli 2010, p. 179).

23 (Python 1973, pp. 30-31): shA ri'i bu byang chub sems dpa' sems dpa' chen po mi skye ba'i chos la bzod pa thob pas ni/ gtong ba gsum la gnas par bya'o// gsum gang zhe na/'di lta ste/ gtong ba dang/gtong ba chen po dang shin tug tong ba la/ de la gtong ba ni rgyal srid yongs su gtong ba'ol/ gtong ba chen po ni chung ma dang/bu dang bu mo yongs su gtong ba'o// shin tu gtong ba ba ni mgo dang/lag pa dang/ rkang pa dang/mig dang lpags pa dang/rus pa yongs su gtong ba ste/. The earliest Chinese translation of the sūtra is Foshuo pini jueding jing 佛説決定毘尼經 (T. 325 = Vinayaviniścayasütra). The relevant passage is found in T. 325 XII 28b29-c2: 得無生忍諸菩薩等。當應修習三種布施。何等為三。王位布施。妻子布施。頭目布施。如是三種名為大施名極 妙施. The translator is named as Dunhuang Sanzang 燉煌三藏. Python follows the general identification of the name as referring to Dharmarakṣa (筇法護) and dates the translation to the period between 265 and 313. For the dating of the text and the first Chinese translation, see (Python 1973, pp. 3-4). The Taishō text of T. 325 is reproduced in ibid., pp. 73-78.

24 (Sathaye 2010, p. 364).

25 (Sathaye 2010, p. 364) 
In Buddhist literary texts, disgust is indeed assigned subsidiary roles to support the plot, resembling how revulsion is transformed into peace in the meditation on the repulsive.

Another facet of the repulsiveness meditation is that it presumes an understanding of the intensity of emotions being manipulated and their interaction with each other. Disgust apparently coexists with fear in harmony, but it can be used to thwart desire. These ideas of human psychology discussed in doctrinal analyses are relatable to Indian aesthetics, which is centrally concerned with the production of aestheticized emotions (rasa), with the loathsome (bhībatsa), fearful (bhayānaka), and erotic (śrnigāra) being recognized among the rasas. According to the earliest surviving work on Indian literary theory, Bharata's Treatise on Drama (Nātyaśāstra), there are just eight stable emotions (sthāyibhāva), "preeminent among all emotions," which turn into respective rasas, through "the conjunction of factors, reactions, and transitory emotions" in a theatrical production..$^{26}$ The transformation of basic human emotions into their aestheticized forms for the enjoyment of literature and theatrical performances is surely very different from contemplative practice used by Buddhist ascetics to control emotions such as desire. Nevertheless, when repulsiveness is portrayed in Buddhist literature, conventions governing its literary representation intervene.

Particularly relevant here is Indian aestheticians' persistent concern with the compatibility between different rasas. ${ }^{27}$ In the case of disgust, what Buddhaghosa speaks of is confirmed by rasa theorists. In a very early opinion, Bharata has noted that disgust (jugups $\bar{a}$ ) is one of very few subsidiary transitory emotions that cannot be used to support the erotic rasa. ${ }^{28}$ Annandavardhana and his commentator Abhinavagupta (c. 1000) both confirm that the loathsome and erotic are diagonally opposed rasas, ${ }^{29}$ while the loathsome and fearful (bhayānaka) are found not to obstruct each other. ${ }^{30}$

That Buddhist literati in the late period of Indian Buddhism were reflecting on the rasa theory can be gauged from Vidyākara's anthology Subhạsitaratnakoṣa. The anthologist was thinking about the loathsome and heroic (vira) rasas in two sections labelled "Cremation Ground" (44) and "Hero" (45). The peaceful (śānta), which was canonized as a rasa by later theorists, was treated in the two sections of "Discouragement" (42) and "Peace" (48). ${ }^{31}$ The erotic rasa is featured in a large number of sections, reflecting its proportionally wider presence in Sanskrit poetry. ${ }^{32}$

Despite the rasa theory's wide influence, some of the best examples of Indian Buddhist literature were composed before it became a mature theoretical discipline. Aśvaghoșa's great Sanskrit epics, for instance, might have been written before the Treatise on Drama assumed a saastric form. ${ }^{33}$ The theory of aestheticized emotions, moreover, remained for centuries only as a part of dramaturgy before it was applied to other areas of literature. For these reasons, Indian aesthetics may not work as a theory that guides literary creation for our present purpose. If the rasa theory developed from the last centuries of the first millennium is used to examine the composition of Buddhist literary texts from an earlier age, the problem of anachronism would be unavoidable. Although this article does take into account to some degree sources of texts as measured by parallel versions, it is not primarily a study of the formation of texts. Rather, the focus here is on the reading and interpretation of texts already formed using perspectives of later ages.

26 Rasas and emotions (bhāva) are treated in the sixth and seventh chapters of the Nātyaśāastra. See (Krishnamoorthy 1992, vol. 1, pp. 254-378). Selected parts of the two chapters, including illustrations of rasas' realization through many contributing elements and an explanation of stable emotions as a category, are translated in (Pollock 2016, pp. 50-55).

27 (Ingalls 1965, pp. 13-15; Pollock 2016, pp. 29-31). See also the entries of "conflicting rasas" and "mixture of rasas" in the latter volume's index section.

28 (Krishnamoorthy 1992, p. 300; Pollock 2016, p. 52). This applies to the erotic rasa that is to be enjoyed (sambhoga), not the unfulfilled kind that is love in separation.

29 See, for instance, (Ingalls et al. 1990, pp. 527-28).

30 Ibid., p. 479

31 (Ingalls 1965, p. 395).

32 As Ingalls has pointed out (ibid., pp. 216, 230), even the subclass of love in separation (vipralambha) is represented at least by two sections of "Women Offended" (21) and "Lady Parted from Her Lover" (22).

33 Aśvaghoșa is thought to have lived in the first or second century CE. See (Tzohar 2019, pp. 188-89). As Pollock notes, Nătyaśástra can only be "vaguely assigned to the early centuries (perhaps third century) CE." See (Pollock 2016, p. 47). 
First of all, it is of interest to read instances of Buddhist literature in light of Ānandavardhana's and Abhinavagupta's literary thought as a way of appreciating Buddhist literary texts. In my opinion, any literary theory that provides insightful interpretations and enhances the experience of the literary qualities of Sanskrit Buddhist literature deserves a chance of being applied to this literature, let alone one that grew out of the classical Indian literary culture. Indian Buddhists from the tenth century onward might have been reading their literary texts using the framework of the rasa theory. It could also be argued that as important as the theory is, they might never have read their literary texts from the perspective of that theory. Instances of emotions in Buddhist literary texts could have been written and read just by being attentive to human psychology, without using the framework of the rasa theory that emerged in the last centuries of the first millennium. In anticipation of this objection, we rely on Vidyākara and Sa skya Paṇdita Kun dga' rgyal mtshan, a Tibetan polymath who was educated by a team of Buddhist scholars from India, to supply the evidence of Buddhist response to the rasa theory and to show that Buddhists have formed some ideas about reading Buddhist literature in light of that theory. These two pieces of evidence are suggestive of a very mild degree of Buddhist participation in the thinking about rasa.

There is a wealth of evidence of Buddhist participation in the discourses on rhetorical figures (alamkāra), which they took up as a theory of literature. ${ }^{34}$ By comparison, there is a paucity of information on how Buddhists reacted to the theory of aestheticized emotions and documented cases of Buddhist application of the rasa theory to examples of literature. It is true that more scholarly efforts are needed to reconstruct Buddhist literary thought retrievable from centuries of commentaries and illustrative poems devoted to alamkāra studies. However, the Buddhist engagement with the rasa theory, as little as it might have been, also deserves a careful look.

\subsection{Disgust Leads to Peace}

We learned from Vidyākara's Subhāșitaratnakoṣa that certain Sanskrit poets and playwrights were skillful at evoking the rasa of loathsome. We have already sampled a macabre verse that he cites from Bhavabhūti's drama Mālatimādhava, which depicts the cemetery scene. How such revulsion inducing descriptions fit into the love story of the maiden Mālatī and the youth Mādhava would be an issue of interest to rasa theorists, who have shown that the loathsome and erotic are mutually incompatible. Even without recourse to specialists, one can see that judicious use of disgust could sometimes properly merge into a plot and even enhance it. Consider, for example, the Sanskrit tale Vāsavadattā written by Subandhu, who has experimented with the repulsive in his masterful prose. In this story, Kandarpaketu and Vāsavadattā mutually fall in love after both had a dream of each other. The hero sets out and finds the heroin. After they eloped, Vāsavadattā vanishes, to be eventually restored to life with the hero's touch on her petrified likeness in stone, but only after a painful separation. ${ }^{35}$

This is clearly a narrative embodying love fulfilled. However, Subandhu gives a vivid description of the grisly sights of the cemetery after Kandarpaketu and Vāsavadattā's escape, ${ }^{36}$ to prepare for the heroin's tragic disappearance after a night spent in the wilderness. After the couple finally reunited, she recounts her ordeal, with details of her flight from the horrors of a battle. ${ }^{37}$ Repulsiveness, therefore, heightens the frustration as love takes a wrong turn. These gruesome episodes also provide occasions for Subandhu's demonstration of the breadth of his descriptive art, replete with such nauseating images from the cemetery as the terrifying howls of awful vampires (vetāla), a profusion of blood from

34 The Buddhist engagement with the alamkāra theory was largely centered around the study and interpretation of Dandin's Kāoyādarśa. It began with the Sanskrit commentary by Ratnaśrijñāna, a tenth-century Buddhist monk from Sri Lanka, and continued with the massive reception of the Kāvyādarśa in Tibetan cultural regions and the Sinhalese adaptation of Dandin's work. Ratnaśrījñāna's commentary is edited in (Thakur and Jha 1957). A new edition of the third chapter is available in (Dimitrov 2011). Another key text on rhetoric used in Southeast Asia is the Pali work Subodhālamkāra.

35 A summary of the Vāsavadattā is available in (Hall 1859, pp. 29-43).

36 Sanskrit edited in (Hall 1859, pp. 241-43) and translated in (Gray 1962, p. 117).

37 (Hall 1859, pp. 293-98; Gray 1962, pp. 137-40). 
the amputation of ears and noses of impaled thieves, and cracking and bursting of human skulls being burnt. The narration of the battlefield incites terror as well as disgust, with vampires taking possession of headless torsos and a demoness (pisāc $\bar{\imath}$ ) curiously trying on an earring fitted with an elephant's foot that had been chopped off. ${ }^{38}$ Such passages also help to widen the spectrum of sentiments captured in the story and add to its emotional depth. ${ }^{39}$

In Buddhist narratives where more focus is often placed on religion, disgust is usually assigned different roles; but even here, there is still a dynamic interplay between the loathsome and erotic, especially in the texts that operate in the high literary register. In the Saundarananda, one of Aśvaghoșa's two epic poems, the foulness of the female body is delineated in a speech by an old ascetic for Nanda, the protagonist who unwillingly takes monk's robe but cannot turn his thought away from his beautiful wife. Langenberg has shown how disgust is used in the poem in the service of the peaceful as the predominant rasa. ${ }^{40}$ The trope of disgust also figures in a similar trajectory of emotion leading to peace in the Buddhacarita, Aśvaghoṣa's poetic rendition of the biography of the Buddha. Here, Vidyākara may lend his anthologist's gaze to help us understand how the rasa of peace, or emphśānta, is seen in a Buddhist's eye.

The images of the palace girls lying inelegantly on the floor in the fifth canto, which prompt Prince Siddhārtha to turn his thoughts to leaving his life of comfort and luxury, have been a theme in the biographies of the Buddha and Buddhist art at least from early centuries CE. While the episode of sleeping girls is absent in the short narratives of the Buddha's departure from home in several Pali suttas of the Majjhimanikāya, ${ }^{41}$ a canonical collection of early Buddhism, it is found in the Mahāvastu and Lalitavistarasūtra. The core contents of the Mahāvastu goes back well before the start of the common era, while materials are added until the fourth century CE. The earliest version of the Lalitavistara has been dated to the middle of the second century CE. ${ }^{42}$ The existence of parallel versions in these two contemporary texts shows that Aśvaghosa was not the originator of the episode. Even though the Lalitavistara is a highly stylized text, it takes the form of a scripture rather than a literary work which the Buddhacarita was designed to be.

The poet Aśvaghoșa paints a disorderly sight with more than a dozen verses of maidens falling asleep after they have entertained the prince with music. ${ }^{43}$ When the verse sequence reaches its climax, we are presented with the unsightly images of snoring, saliva oozing from the wide-open mouth, or unconscious bodies with open and motionless eyes, where a comparison between a sleeping body and a corpse is implicit. ${ }^{44}$ Describing the female body in unfavorable terms in the service of the practice of male celibacy has drawn critiques from feminists and modern authors, with one writer calling the presentation in the Lalitavistara "most unkind to the feminine sex." ${ }^{45}$ The parallel versions in the Lalitavistara and Mahãvastu describe the retinue of women seen through the eye of the prince. ${ }^{46}$ The Lalitavistara is more emphatic on the idea of unattractiveness, detailing more reflections of the prince and leading to his meditation on his own body. These thoughts conclude with verses on the body.

38 As Singh points out, disgust is also featured in the description of the sandy bank of the sea when Kandarpaketu was about to commit suicide, as love in separation reaches its climax. See (Singh 1993, p. 69).

39 For a profile of rasas featured in the Vāsavadattā, see ibid., pp. 63-72.

40 (Langenberg 2017, pp. 82-86).

41 For a list of these Majjhimanikāya suttas that deal with the Buddha's renunciation and his enlightenment and a summary of their contents, see (Lamotte 1988, pp. 648-50).

42 For a recent survey of the textual history of Lalitavistara and scholarship, see (He 2012, pp. 3-10).

43 Buddhacarita 5.48-62. See (Johnston 1998, part 1 (Sanskrit Text), pp. 51-54) and translation in part II: 70-73. (Olivelle 2008, pp. 144-51).

44 Buddhacarita 5.59-5.61.

45 (Foucher 2003, p. 75).

46 For the version in the Lalitavistara, see (Lefmann 1977, p. 206). An English translation is found in paragraphs 15.37-39 in (Dharmachakra Translation Committee 2013). For the version in the Mahāvastu, see (Senart 1890, p. 159; Jones 1952, pp. 154-55). 
The key verses have been cited in the previous section, which mirror the repulsiveness meditation that goes through impure parts of the body. ${ }^{47}$

If one pays close attention to Aśvaghoșa's version, however, one finds that the unsightly is mixed with erotic descriptions. Aśvaghoșa's intimate knowledge of the epic Rāmāyana has already been established. ${ }^{48}$ It is possible that Aśvaghoṣa's point of reference is the book of Sundarakānda of the Brahmanical epic, where the beautiful scene of sleeping female companions of the demon king Rāvana is portrayed with tenderness, while the female demonesses (rākșasì) guarding the heroin Sītā are described as deformed and grotesque. Just as in Rāvana's inner quarters, the women in the service of Prince Siddhārtha fall unconscious after a night of entertainment, their ornaments in disarray. One sleeps while embracing her tambour, echoing women's bodies intertwined in the presence of Rāvana, with some kissing others who are mistaken to be their lovers. ${ }^{49}$ We need to point out that the versions in the Mahāvastu and Lalitavistara also have their shares of resemblance to the Rāmāyana. The Mahāvastu has various service girls holding musical instruments or embracing their neighbor in sleep; in the Lalitavistara, the girls are even called a host of demonesses (rāksasīgana) ${ }^{50}$ However, it is Aśvaghoșa's sleeping girls who clearly have both delightful and dreadful sides, as if the Buddhist poet was merging two female prototypes in the Sundarakand disgusting and erotic.

The sense of ambivalence toward these two conflicting emotions is significant, as we will see later. But in the present context, Aśvaghoṣa's Siddhārtha gives thoughts to the feminine attractiveness and the underlying impurity, noting the mutation brought about by sleep. ${ }^{51}$ There arises a form of disgust somewhat intellectually oriented, which then "prompted an urge to depart (niścikramișā) that night.".52 In the Lalitavistara, the link between the contemplation on the repulsive and the prince's determination to renounce worldly life is also clearly visible. ${ }^{53}$ The sight of sleeping girls in the palace is one of a series of events that lead to the future Buddha's departure from worldly life in the Life of the Buddha. Being the last in that series, it is a significant stimulant that moves the plot forward. It also establishes a direct link between disgust and world renunciation in this paradigmatic narrative.

Aśvaghoșa's depictions of women are highly varied, and he is not restrained by his scriptural sources in the manners of expression. Even while his stated goal is "the attainment of tranquility (vyupaśāntaye)," established convention intervenes in his literary creation as he follows "the law of poetry (kāoyadharma). ${ }^{\prime 54} \mathrm{He}$ devotes much of the fourth canto of the Buddhacarita to a portrayal of women amorously showing their love toward the prince. ${ }^{55}$ Their display of affection, however, is ignored by Siddhārtha, who has by this point turned his thoughts inwardly toward religion. His initial change of heart occurs in the third canto of the poem where he encounters an old man on a tour of the city of Kapilavastu. This transformative event is preceded by a depiction of the urban scene reconstructed through the poet's imagination. ${ }^{56}$ The womenfolk of Kapilavastu again dominate that glimpse of the city's streets painted by Aśvaghoṣa. ${ }^{57}$ In the Mahāvastu and Lalitavistara, there is

47 While the Sanskrit text that we have may be from a later age, these key elements from the Lalitavistara are found in the earliest extant Chinese translation of the sütra made at the beginning of the fourth century. See T. 186 III 504c15-505b9.

48 (Hiltebeitel 2006, pp. 247-54; Johnston 1998, part II: xlvii-1).

49 See (Goldman 2000, pp. 105-16). Some of the earlier verses in the episode in the Buddhacarita, such as 5.49, 5.54, and 5.55, are clearly describing sleeping girls' beauty. With 5.59-5.61, the disgraceful reaches its peak.

50 (Lefmann 1977, p. 206).

51 Buddhacarita 5.63-5.65. (Johnston 1998, vol. 1, p. 54, vol. 2, pp. 73-74; Olivelle 2008, pp. 150-51).

52 Buddhacarita 5.66b. (Johnston 1998, vol. 1, p. 54, vol. 2, p. 74; Olivelle 2008, pp. 150-51). Abhinavabhāratī records a view which mentions disgust for young woman, even though they are considered by the entire world to be desirable. See (Masson and Patwardhan 1969, pp. 115, 129). See also (Gerow 1994, p. 198).

53 (Lefmann 1977, p. 209); T. 186 III 505b21-23.

54 Saundarananda 18.63. See (Johnston 1975, Part I (Sanskrit text), p. 141, Part II (English translation), p. 117).

55 The section reflects a feature of a long poem (Mahākārya) that the critic Dandin phrases as "festivity of drinking and love" (madhupānaratotsava) half a millennium later. See (Kāvyādarśa 1.16d, in Thakur and Jha 1957, p. 12; Dimitrov 2002, pp. 160-61).

56 Buddhacarita 3.10-3.24. See (Johnston 1998, vol, 1, pp. 21-23, vol. 2, pp. 33-36; Olivelle 2008, pp. 62-67).

57 The depiction of women occupies Buddhacarita 3.13-3.21 and 3.23-3.24 of the verse sequence identified in the last note. 
no comparable prelude to the sight of the old man. The Mahāvastu says no more than the prince's experiencing of pleasant sights, sounds, and scents and receiving salutations. ${ }^{58}$ In these two parallel versions, the prince never reached the park on these excursions to meet the women described in the fourth canto of the Buddhacarita. In content, design, and level of detail, the portrayal of women in the two cantos clearly serves the purpose of a literary work.

Rather than highlighting the grotesque or amplifying temptation unwanted, Aśvaghoșa portrays the female spectators of the procession with remarkable freshness and dignity. Beautiful and beaming faces emerge from narrow balconies, like bunches of flowers; some rush to see the prince, with their jingling girdles and tinkling anklets frightening away birds; the steps of some, though in haste, are hampered by their large hips and breasts; another lady, out of modesty, pauses to conceal her ornaments worn for intimacy. ${ }^{59}$

Following the description of the street scene is the well-known sight of an old man. The prince's response in this case is affective, in contrast with his more cerebral reaction to the sight of sleeping girls. On learning about the inevitability of old age as a human destiny, he was "shaken", and he "was deeply perturbed, like a bull hearing the sound of thunderous lightning nearby." 60 Viewed from the perspective of the later Indian aesthetic tradition, what sets in at this point, to be carried in the rest of the epic poem, is the peaceful sentiment (śantarasa). Masson and Patwardhan, for instance, regard Aśvaghosa's major works as very early literary expressions of the rasa of peace. ${ }^{61}$ According to Ānandavardhana, the rasa of peace is the aestheticization or full development of a type of happiness that consists of the complete cessation of yearnings for objects of sense. ${ }^{62}$ Abhinavagupta's commentary identifies this kind of happiness as the stable emotion of the rasa of peace. ${ }^{63}$ For this promulgator of the developed rasa theory, the peaceful is evoked through a process of suggestion of its corresponding stable emotion. This process, moreover, is achieved by means of presenting that stable emotion's object and things that stimulate it (vibhāva), reactions or the effects of the emotion (anubhāva), and transitory emotions or feelings that accompany it (vyabhicāribhāva) - a process which is required in the production of other rasas. ${ }^{64}$ The common terms that Indian writers use to describe the stable emotion of the rasa of peace are nirveda, disillusionment or indifference to worldly things, and tranquility (śama). ${ }^{65}$

In the process of defending the existence of the rasa of peace, Abhinavagupta addresses an objection, which attempts to deny śantarasa by suggesting that the peaceful is no more than a part of the loathsome. This objection is based on the idea that the peaceful takes the form of disgust toward objects of sense. If an aestheticized emotion takes disgust to be its stable emotion, it is none other than the loathsome. Abhinavagupta's reply to the objection presents two ideas. ${ }^{66}$ First, the emotion disgust that occurs is not a stable emotion; rather, it is a transitory emotion (vyabhicāribhāva). It is significant that while refusing to equate the peaceful sentiment with the loathsome, Abhinavagupta also does not

58 (Senart 1890, p. 150; Jones 1952, p. 146).

59 Buddhacarita 3.21, 3.15, 3.16, and 3.17.

60 Buddhacarita 3.32a: calitah; 3.34cd: samvivije mahāśaner ghoṣam ivāntike gauh. (Johnston 1998, vol, 1, p. 24, vol. 2, pp. 33-36; Olivelle 2008, pp. 62-67). Aśvaghoșa also pays close attention to the prince's emotional response to his sights of a sick person and a dead man later on in the canto.

61 (Masson and Patwardhan 1969, pp. 3-4).

62 (Ingalls et al. 1990, pp. 520, 692). The Sanskrit is in (Masson and Patwardhan 1969, p. 94): śāntaś ca tṛ̣nāksṣayasukhasya yah paripoșas tallakșano rasah pratìyata eva.

63 For Abhinavagupta's commentary, see (Ingalls et al. 1990, pp. 520-21; Masson and Patwardhan 1969, p. 96).

64 (Tubb 1985, p. 150). The developed rasa theory emphasizes the use of suggestion, and it also follows Bharata's well-known aphorism, which states that "rasa arises from the conjunction of factors, reactions, and transitory emotions." See (Pollock 2016, p. 50).

65 Abhinavagupta provides a detailed analysis of śantarasa along with possible candidates of its stable emotion in the Abhinavabhāratī. For the Sanskrit and an English translation, see (Masson and Patwardhan 1969, pp. 113-43). For an updated translation, see (Gerow 1994, pp. 192-208).

66 On Abhinavagupta's response to the anticipated objection involving the question of disgust, see (Ingalls et al. 1990, pp. 525, 526n4; Masson and Patwardhan 1969, pp. 94, 96). 
deny that disgust plays a part in moments of peace. Theorists defending the rasa of peace clearly allow for an affective dimension of the sentiment, as we also find in the literary enactment of renunciation.

Aśvaghoṣa's representation of Siddhārtha's encounters with old age, sickness, and death is indeed attentive to the character's emotional response in the narrative unfolding of the theology of suffering. In the prince's two subsequent tours of Kapilavastu, he was also shaken (pravep, samkșubh) by the sights of sickness and death, his mind affected by dejection (visad) and, in the case of the sick person, the feeling of compassion (anukampa, karunāya) ${ }^{67}$ The emotional responses of the prince to the sights of old age, sickness, and death are largely absent in the Mahāvastu and Lalitavistara. For the proponents of śantarasa, what Aśvaghoșa has presented would be reactions and subsidiary emotions that, along with disgust, contribute to the rise of the rasa of peace. Moreover, Aśvaghoșa's Siddhārtha also exhibits a cognitive side in the episodes that lead to his renunciation. In the Abhinavabhāratī, his commentary on the Nātyaśästra, Abhinavagupta prefers to identify knowledge of the truth (tattvajñana) as the stable emotion of the rasa of peace. His more specific idea that associates knowledge of the truth with knowledge of the self (ätmajñāna) does not apply to the biography of the Buddha. ${ }^{68}$ Nevertheless, it is worth noting that the Buddhist tradition has emphasized the role of understanding in this junction of the biography by framing the prince's encounter with old age, sickness, and death as an event of discovery of the basic human condition.

In the hand of Aśvaghoṣa, the response of disgust is then presented as turning away from pleasure and enjoyment: "How can I find pleasure?" and, "My mind is repelled from pleasures, and it appears, as it were, to recoil." ${ }^{\prime \prime 9}$ Rudrata has a nearly perfect description of this situation when he characterizes the rasa of peace in the following terms:

A state in which the hero is without desire, the peaceful has right knowledge as its origin.

Right knowledge arises from relinquishing confusion and attachment to the object of sense.

There arise in this case fear of birth, old age, and death, etc.,

an impression of disgust at the object of sense, and indifference to pleasure and pain. ${ }^{70}$

The commentator Namisādhu differs from Abhinavagupta by identifying disgust (vairasya), or bad taste, as one of the reactions of śantarasa. ${ }^{71}$ Just as Langenberg has suggested, it is clear from the perspective of the Indian theoretical tradition that there is an aesthetic for the whole range of suffering in artistic representation.

To support the idea that disgust is not a stable emotion, Abhinavagupta makes a further point that it is eradicated in the final stage of peace. ${ }^{72}$ The Subhāistaratnakoșa offers a perspective on the question of stages when the Buddhist anthologist takes up the peaceful in earnest toward the end of his anthology. Vidyākara reserves two sections of his anthology for the exemplification of peace under the titles of "Discouragement" (nirveda) and "Peace" (śānti). Commenting on these sections, Daniel Ingalls suggests that Indian critics in favor of postulating the rasa of peace conceive of its unfolding in stages. The "biography of the soul" contains the "first frustration and discouragement (nirveda) with worldly life," through "turning one's back on the world (vairagya)," to finally reaching the goal of tranquility and calm (śama) ${ }^{73}$

67 Buddhacarita 3.43, 3.45, 3.58, and 3.60. (Johnston 1998, vol. 1, pp. 26, 28, vol. 2, pp. 39, 42; Olivelle 2008, pp. 74-75, 78-81).

68 (Masson and Patwardhan 1969, pp. 115, 130-31; Gerow 1994, pp. 199-200).

69 Buddhacarita 3.37c: kuto ratir me; 3.47: me ... ratibhyah pratyāhatam samkucatìva cetah. Cf. 3.62cd. (Johnston 1998, vol. 1, pp. 25, 26, 29, vol. 2, pp. 38, 40, 43; Olivelle 2008, pp. 74-75, 78-79, 82-83).

70 (Masson and Patwardhan 1969, p. 93): samyagjñānaprakrtị śānto vigatecchanāyako bhavati/ samyagjñānam vișaye tamaso rāgasya cāpagamāt// janmajarāmaranāditrāso vairasyavāsanā visaye/ sukhaduhkhayor anicchādveșāv iti tatra jāyante//.

71 (Masson and Patwardhan 1969, p. 94n1). Like Abhinavagupta, Namisādhu recognizes right knowledge as the stable emotion. For him, vibhāva consists of sense objects. Fear of birth and so on, disgust, and indifference are reactions.

72 (Ingalls et al. 1990, p. 525; Masson and Patwardhan 1969, p. 97).

73 (Ingalls 1965, p. 385). Nirveda or śama are the common candidates for the stable emotion of śântarasa. In terms of textual sources, Tubb has shown that śama is presented in the interpolated passage in the Nātyaśāstra that deals with śāntarasa, 
The "Discouragement" and "Peace" sections indeed evince a conception of a life in pursuit of peace in two stages. Vidyākara apparently takes nirveda to be the stage of disillusionment with worldly life, as the poems of the section speak of disappointments and troubles in life of various forms. ${ }^{74}$ Two verses positioned toward the end of the section (nos. 1512 and 1514) take up aging and death as the basic problems of life. The nirveda section is then followed by one treating specifically the topic of old age, while the next section on the cremation ground deals with death through its own angle. If the nirveda poems signify disillusionment and departure from worldly life, the section of "Peace" largely embraces the spectrum of life after retiring from the world. ${ }^{75}$ Vidyākara's peace encompasses many facets of renouncers' life, confining itself neither to the lives of exemplars of the ascetic career nor to the culmination of that way of life, such as the Buddha's final nirvana. ${ }^{76}$ In fact, the peace sections of the Subhāsitaratnakoṣa cannot be described as Buddhist in content, with Bhartṛhari's Vairāgyaśataka and Silhana's Śantiśataka being the two largest contributors of selected poems.

By the turn of the millennium, Aśvaghoṣa might have fallen into oblivion, as his major works seem to be unknown to Vidyākara and critics like Ānandavardhana and Abhinavagupta. ${ }^{77}$ Indeed, we cannot identify specific Buddhist works as the main textual basis behind Vidyākara's ideas about peace. It is true that there are other biographies of the Buddha, but many take the form of a scripture or form a part of the vinaya. The Buddhacarita is rather distinctive in being a book-length treatment that is written as a work of Sanskrit poetry. As such, it shows more literary concerns in such areas as the incorporation of erotic elements, and it is particularly amenable to analysis using the framework of the Indian theoretical tradition. In the case of the Subhassitaratnakoșa, it is reasonable to expect that for the Buddhist anthologist, the knowledge of the Buddha's biography in general terms conditioned the creation of "Discouragement," "Old Age," "Cremation Ground," and "Peace" sections. ${ }^{78}$ The poems selected from the wider literature, on the other hand, diversify and enhance the aesthetic experience of these topics. Moreover, Vidyākara's treatment of peace under two sections brings a later perspective to bear on the literary biography of the Buddha that is the Buddhacarita. As far as the sentiment of peace is concerned, the story of the Buddha is to be experienced as a bifurcated narrative consisting of the renunciation of worldly life and life of peace lived. In these ways, the Subhạsitaratnakoṣa sheds new light on the Buddhacarita, even though Vidyākara might not have read the latter work.

The critical perspectives of Ānandavardhana and Abhinavagupta, moreover, prove to be illuminating on the relationship between the erotic and peaceful. Even the limited examples presented in this study are sufficient to illustrate that this relationship manifests in a variety of ways in Buddhist literary texts. ${ }^{79}$ Their theory explains, for example, why the procession of the prince in the third canto, clearly tinged by an erotic mood, transitions so well into Prince Siddhārtha's initial experience of disillusionment,

while other critics prefer nirveda as śānta's stable emotion, borrowing it from the list of transitory emotions presented in the older portion of the work, where it is listed as the first of these emotions. See (Tubb 1985, p. 146).

(Kosambi and Gokhale 1957, pp. 253-62; Ingalls 1965, pp. 385-95).

75 (Kosambi and Gokhale 1957, pp. 275-83; Ingalls 1965, pp. 418-27). Some verses of the section still continue the theme of frustration and discouragement, as Ingalls points out (ibid., p. 418).

76 Vidyākara has been lauded for exhibiting no sectarianism in his work. See (ibid., p. 31).

77 (Ibid., 32n24). (Ingalls et al. 1990, p. 5). Cf. (Masson and Patwardhan 1969, pp. 3-6).

78 It is worth noting that disgust and renunciation, two key topics treated in this essay, are represented here.

79 Daniel Ingalls has said that sensuousness is a quality of high Sanskrit poetry that is difficult for Buddhist poets to emulate because of their religious beliefs. See (Ingalls 1965, pp. 58-59). However, Buddhist literary texts, unlike Buddhist scriptures, contain many instances of sensuous and erotic descriptions. Among the exceptions noted by Ingalls, Aśvaghosa has shown an interest in different ways of portraying women. Examples from the Buddhacarita referred to in this study include the disgusting side of the sleeping girls (fifth canto), attempts at seduction being ignored (fourth canto), and the description of women in an urban setting that transitions into the episode of renunciation. In canto twenty-two, the subdued demeanor of $\bar{A}$ mrapāli in religious devotion demonstrates yet another form of feminine beauty. In the Saundarananda, the erotic unfolds in such ways as the conjugal love between husband and wife, attachment to the former lover as a distraction to the ascetic life, and attraction to heavenly maidens. In the Nāgānanda, we encounter an amplified treatment of the love and marriage of Jīmūtavāhana identified as a bodhisattva, who later sacrifices himself to save nāgas. The love between Jīmūtavāhana and Malayavatī, however, is known to adaptations of this legend in the Kathāsaritsāgara and Avadānakalpalatā. 
even when the erotic and peaceful are mutually incompatible. ${ }^{80}$ When two rasas obstruct each other, the two critics explain, the conflict can be resolved by the intervention of a third rasa. ${ }^{81}$

In the third canto of the Buddhacarita, the transition from the of excitement of female spectators to the disillusionment of the prince is not achieved by the insertion of another rasa. However, it is equally effective, being marking by the modesty and propriety of the women, who "murmured with no emotion other than pure hearts, 'Blessed is his wife,'"182 before they blended into the crowd. On his part, the prince was delighted when he saw "well-behaved citizens addressed in clean and dignified clothes (paurair vinìtaih śucidhìraveșaih)." He "felt he was somehow born again (mene punarbhāvam ivātmanaś)," now ready for a life-changing encounter. ${ }^{83}$ Our critics again point out that when elements of the erotic come in touch with a rasa that is opposed to it-here Abhinavagupta uses the peaceful in his example-it is not a blemish, as it can attract the attention of the audience or makes a poem beautiful. ${ }^{84}$ This describes well the function of Aśvaghoșa's female spectators, who then recede into the background to passively witness the prince turning his back on the worldly objects.

To summarize, disgust can either be seen as revulsion from worldly objects, which plays a subsidiary but important part in the evocation of the rasa of peace, or, taking the form of an experience of the repulsive or unsightly, it serves as a stimulant that prompts the departure from the worldly life in literary texts. Buddhist narratives involving disgust in the latter circumstance could take on a structure that resembles the progression of the meditation on the repulsive, which moves from revulsion to tranquility and calm. One should not underestimate the normative status of the biography of the Buddha in conditioning the Buddhist literary tradition. We find, for instance, another literary use of the theme of repulsiveness in the Aśokāvadāna, which narrates the legend of Aśoka, the monarch of the Maurya Empire and paradigmatic patron of Buddhism. The contemplation on the repulsive performs a similar function in Aśoka's conversion to Buddhism.

The incident occurs when Aśoka was still a ruthless tyrant, who had a house of torture and execution erected. Samudra, a Buddhist monk, inadvertently enters the hellish prison. Given just seven days to live, the terrified monk applies himself to Buddhist teachings, as the chamber of torture has all the meditation props that a cemetery normally supplies. After he achieves the saintly state of an arhat, Aśoka comes to witness the marvel of Samudra's display of miracles, after which the king converts to Buddhism. This episode includes the Buddhist monk's witness of the execution of a concubine of Aśoka's and a youth, towards whom she was caught to have shown affection, by grinding in an iron mortar with pestles. The reference to repulsiveness is unmistakable in Samudra's astonishment at the perishing of the lady: "Where is the beauty of her face? Where has the one with beautiful limbs gone?" 85 The event is an occasion not for Aśoka's renunciation but his conversion, as he is to lead a life as a householder. Repulsiveness, thus, serves as a direct cause of Samudra's enlightenment and an indirect cause of Aśoka's conversion, which is triggered by wonder (adbhuta).

\subsection{Mutilated Body and Self-Sacrifice from the Perspective of Sa skya Pandita's Buddhist Discourse on Rasa}

We have illustrated the significant roles of disgust in Buddhist narratives of renunciation and in the experience of the peaceful rasa. Another notable site where horrifying images typically invoking

80 On the incompatibility between the erotic and peaceful, see (Ingalls et al. 1990, pp. 519, 532).

81 (Ibid., pp. 524, 527-28). The example that Ānandavardhana provides, which Abhinavagupta comments on, features the intervention of the heroic in the conflict between the erotic and loathsome in a single versified sentence.

82 Buddhacarita 3.23: dhanyāsya bhāryeti śanair avocañ śuddhair manobhih khalu nānyabhāvāt. (Johnston 1998, vol. 1, p. 23, vol. 2, p. 36; Olivelle 2008, pp. 66-67). In the following verse, the women pay the prince their respect, thinking that he "will devote himself to dharma after giving up the royal splendor." The Buddhacarita presents the future Buddha's renunciation as predestined, with the sights of old age, sickness, and death and his departure from the palace being arranged by the gods.

3 Buddhacarita 3.25 .

84 (Ingalls et al. 1990, pp. 531-33).

85 The story of Aśoka and Samudra is narrated in (Vaidya 1999a, pp. 237-40). For an English translation and an analysis, see (Strong 2008, pp. 214-18, 73-76). The half verse cited here reads: kva tadvadanakāntitvam gātraśobhā kva sā gatā/. 
disgust occur is Buddhist narratives of compassionate acts of self-sacrifice. The genre of tales of the Buddha as a bodhisattva in his previous lives (jätaka) dedicating himself to the good of others often features the protagonist's giving away of his body or limbs to a petitioner. ${ }^{86}$ It is only a matter of time that the gruesome aspect of the self-sacrifice comes to attract some closer attention. In the Jātakamāla a collection of Sanskrit jätaka tales from the early centuries CE, Āryaśūra has occasionally given that aspect a literary touch. In the story of Śibi, for instance, the king who has given away his eyes to a brahmin is said to be the "one whose face is like a lotus pond without lotuses." ${ }^{87}$ In the Maitribala story, Āryasuura goes to some lengths to show how the king offers his own flesh, which he cuts out from his body with a sword, and his blood to ogres as food and drink. ${ }^{88}$ For Āryaśūra, who is particularly interested in ethical matters and psychological descriptions, the frightful details strengthen the nobility of the bodhisattva's character. As the progenitor of ornate Sanskrit literary texts that are based on jātaka stories, Āryaśūra's Jātakamālā is particularly relevant here since we will be looking at the critical comments on this genre made by Sa skya Paṇitita, who appears to have referred to Âryaśūra's work as one that he has studied. ${ }^{89}$

The Sanskrit drama Nāgannanda, or Joy of the Nāgas, written by King Harșa of Kannauj in the seventh century is a particularly well-known work, whose Tibetan rendition was placed in the Jātaka (Skyes rabs) section of Bstan 'gyur. As far as the source of Harșa's work is concerned, major recent studies accept the conclusion reached by Bosch in an early research that the Nāgannanda was derived from the lost story collection Brhatkathā, which contains the original forms of the legend that were further adapted in the Kathāsaritsāgara, Bṛhatkathāmañjarī, and Avadānakalpalat̄̄. ${ }^{90}$ There is not an extant canonical jätaka story that can serve as Harșa's prototype. The question that must be considered here is in what sense the Nāgannanda can be considered Buddhist, if it is at all. It is not sufficiently convincing to argue that the drama was based on a lost jätaka as there is no strong evidence to support it. ${ }^{91}$ Bosch has argued that the Jīmūtavāhana legend was originally not Buddhist. However, origin is not the single factor that decides a work's religious identity as there are many Buddhist tales that were not connected with Buddhism in their original forms. Regardless of whether a pre-Harsa Buddhist version of the Jìmūtavāhana legend existed, Harșa has indicated that the drama is at least partly, if not primarily, to be enjoyed as a Buddhist work. Not only is the content of the drama after the three initial acts compatible with the Buddhist doctrine, the hero has also been called a bodhisattva. ${ }^{92}$ Perhaps more importantly,

86 Some modern readers have expressed unease at what they perceived to be altruism being carried to excess, but the subject appears to be endearing to Asian Buddhists and some literary critics.

87 Sibijätaka 29b. (Vaidya 1999b, p. 12): vipadmapadmākaravaktrah. See (Khoroche 1989, p. 15).

88 (Vaidya 1999b, pp. 50-51; Khoroche 1989, pp. 54-55).

89 Sa skya Pandita mentions "Skyes pa'i rabs" (Jātaka) as a work (or works) that he has studied. See (Sa pan Kun dga' rgyal mtshan 2004, p. 85). Both Matthew Kapstein and Jonathan Gold take the word to mean Jātaka[mālā of Āryaśūra]. See (Kapstein 2003, p. 779; Gold 2008, p. 154). Their speculation is reasonable since Āryaśūra's Jātakamālā was translated during the early dissemination of Buddhism in Tibet, and its wide influence in Tibet has been demonstrated in Kapstein's and Dan Martin's studies listed in the "references" section.

90 (Bosch 1914; Steiner 1997, pp. 25-29, 127-30; Skilton 2009, p. 4).

91 (Steiner 1997, p. 127). Harșa's own words that his work is dependent on a vidyādharajātaka, which have been used to support the position that the drama is based on a Buddhist exemplar, are cited here. However, Steiner proceeds to argue in the following pages that the author does not mean by jātaka a separate Buddhist work. A Buddhist text translated into Chinese by Zhi Qian 支謙, who was active mainly in the first half of the third century, contains the narrative of the bodhisattva in a former life who saves nāgas from Garuḍa. See T. $153 \mathrm{III}$ 68b29-69a16. This story was recently referred to in the discussion of the source of the Nāgānanda in (Zhang 2018, pp. 342-43). The narrative contains some elements of the Jīmūtavāhana legend, but is not yet recognizable as its earlier version, as the character who saves the nāgas is the king of nāgas, who does not sacrifice himself. The combination of this source and the fact that other adaptations of the Jìmūtavāhana legend contains references to the hero as a bodhisattva shows that we may not have in our possession the full record of the history of the legend.

92 Steiner lists places where the hero is referred to as a bodhisattva in the Nāgānanda, Kathāsaritsāgara, Bṛhatkathāmañjarī, and Avadānakalpalatā. He follows Bosch in regarding the Jīmūtavāhana legend as not Buddhist originally, but he appears to entertain the possibility that the legend in the Brhatkathā was already Buddhist. See (Steiner 1997, p. 128nn4-5). 
the author composed verses venerating the Buddha in the prologue of the work; the Nāgannanda is also influenced by Candragomin's Buddhist drama Lokānanda in many ways. ${ }^{93}$

From the point of view of the Nāgannanda's reception, many Buddhists apparently regarded the drama as a Buddhist work, judging from the report of the Chinese pilgrim Yijing, the evidence of its study by Tibetan scholars such as Sa skya Paṇdita and Khams sprul Bstan 'dzin chos kyi nyi ma, and its inclusion in the Jātaka section of the Bstan 'gyur. ${ }^{94}$ It is noteworthy that even Abhinavagupta, who brings Brahmanical views to bear on the understanding of the drama, concedes that the hero of the drama can be viewed as a bodhisattva. ${ }^{95}$ As this study focues more on the reception of a work than its origin, we can safely put the question whether the Nāgannanda is Buddhist behind us.

Unlike the Buddhacarita, we could expect a seventh-century playwright to be informed by ideas about rasa. We may very well consider how Harșa used Bharata's Treatise on the Drama, but again such an analysis would pivot toward the process of literary production. ${ }^{96}$ What is also available to us are specific comments on the Nāgannanda itself left by a number of prominent later theorists. It is clear that when we analyze Buddhist literature from the perspective of the rasa theory, the Nāgannanda cannot be easily bypassed. Indeed, what major rasa theorists have spoken about the Nāgannanda are relevant when it comes to the question of rasa in relation to many other instances of Buddhist literature.

The Nāgannanda enacts the personal sacrifice of Jìmūtavāhana, the prince of a race of mythical beings, in the second part of the drama that begins with the fourth act. The hero voluntarily gives up his life to save Śankacuda, a member from the community of serpent-like năgas, who had been offered as a victim to Garuda, the lord of birds. Harșa's drama juxtaposes this religious narrative with the story of the love and marriage between the hero and the heroine Malayavati in the first three acts. ${ }^{97}$ For some critics, the juxtaposition of love and self-sacrifice as two major themes of the same work raises the question of the coherence of the Nāgānanda as a theatrical experience. The opposition between love and the hero's altruistic intention is epitomized in a verse in which the hero considers the touch of the stone slab on which he will be killed to be more pleasurable than that of his beloved wife when she is "wet with the juice of sandal from the Malaya mountain." 98

Scholarship from the final decades of the last century has revealed that there are five basically independent recensions of the Nāgannanda. One of the features that distinguish the older Nepalese and Tibetan recensions from others is the fact that they divide what is the final fifth act of the drama in the other recensions into two acts: the fifth and sixth..$^{99}$ Since we will be examining both Sanskrit and

93 See (Hahn 1970; Ghoșa et al. 1991, pp. I, VI-X). Authors who are sympathetic to Buddhism-in the case of Harsa, a known supporter of Buddhism-may compose Buddhist works even if they are not Buddhists themselves. Kṣemendra's Avadānakapalatā is a case in point.

94 Yijing's observation of the Nāgānanda's performance in India is found in T. 2125 LIV 228a6-8: 又戒日王取乘雲菩薩以身 代龍之事。緝為歌詠。奏諧絃管令人作樂。舞之蹈之流布於代. Takakusu's English translation is quoted in (Steiner 1997, p. 129n2). On Sa skya Paṇita's study of the Nāgānanda, see (Kapstein 2003, p. 779; Gold 2008, pp. 155, 181). For Khams sprul's citation of Nāgānanda 4.4 in his commentary on the Kāoyādarśa, see (Khams sprul Bstan 'dzin chos kyi nyi ma 1986, pp. 72-73).

95 (Masson and Patwardhan 1969, pp. 117, 118, 134-37; Gerow 1994, pp. 203, 205).

96 There is no doubt that such a study would be useful. Additional materials available for such a study include Kashmirian adpations of the Jīmūtavāhana story (Kathāsaritsāgara, chapters 22 and 90; Bṛhatkathāmañjarī 4.36-109 and 9.766-935; and Avadānakalpalatā, pallava 108) written several centuries later, which present such a project with another set of methodological problems. If the Nātyaśāstra is used for the analysis of rasas in the Nāgānanda, śāntarasa and the new subtype of the heroic rasa, dayāvira, would not come into the purview. Ideas about the conflict of rasas would also be rudimentary.

97 As noted above, Malayavatī is known to other adaptations of the Jīmūtavāhana legend such as the Kathāsaritsāgara and Avadānakalpalatā.

98 Nāgānanda 4.22 in the Tibetan (in the edition cited below), Nepalese, and South Indian recensions. For the Tibetan translation, see (Bhattacharya 1957, p. 173). For the Sanskrit of the South Indian recension, see (Śâstrî 1917, p. 224); the Sanskrit and English translation are found in (Skilton 2009, pp. 162, 163). For the North Indian recension, see (Ghoșa et al. 1991, p. 53).

99 See (Hahn 1970; Ghosa et al. 1991, pp. I-XV). For a concordance of the representative editions of the five recensions, see (Steiner 1997, pp. 314-15). 
Tibetan critical receptions of the drama, representative editions of the Tibetan text and two Sanskrit recensions- the South and North Indian recensions-will be used. ${ }^{100}$

Following Ānandavardhana's doctrine that the conflict between two rasas in succession can be rendered harmless by the intervention of a third, Abhinavagupta elaborates on how the Nāgannanda resolves the tension between the erotic and peaceful, the latter of which being seen as the pervasive rasa emerging not just in the second part of the play where it dominates. He shows that peace has been hinted early on in the first act and that the transitions into the erotic rasa and out of it are carefully crafted with intervening sentiments and elements. ${ }^{101}$ According to another critical perspective, Jīmūtavāhana's marriage with Malayavatī aids him in the accomplishment of his compassionate act. ${ }^{102}$ In short, for some critics, the hero's romance is subordinated to his self-sacrifice, and this point is perhaps signaled in the comparison between the hard slaughter stone and heroine's anointed body.

On the question of the predominant rasa of the Nāgannanda, critical opinions are divided between the peaceful and heroic. Ānandavardhana's Dhvanyāloka and Abhinavagupta's commentary on it begin by identifying the play's rasa as that of peace, ${ }^{103}$ but they later admit that the rasa in question is a variety of the heroic called heroism of compassion (dayāvira). They reason that false notion of the self is absent in this variety of heroism, while egoism is present in heroism of munificence and heroism of religion. ${ }^{104}$ Here, Abhinavagupta cites an old distinction made in the Treatise on the Drama, where the heroic is classified into three varieties of heroism in munificence (dānavira), religion (dharmavira), and battle (yuddhavira). ${ }^{105}$ The heroism in compassion introduced here is an act of selflessness, which is an essential character of the rasa of peace. The maneuver that Ānandavardhana and Abhinavagupta make in this context is hermeneutical, and when they further note that heroism in compassion is just a name for a variety of the peaceful, ${ }^{106}$ they have not relinquished the position that the predominant sentiment of the Nāgananda is the rasa of peace.

Some critics on the other hand prefer to see heroism as the predominant sentiment of the Nāgānanda. Abhinavagupta appears to opt for heroism in the Abhinavabhāratī as he regards enthusiasm characterized by compassion to be the predominant emotional state in Harsa's play. ${ }^{107}$ According to Gerow, Abhinavagupta has not changed his position since he regards heroism in compassion to be synonymous with peace in his commentary on the Dhvanyāloka. ${ }^{108}$ Dhanika, another influential critic, maintains that the predominant rasa of the play is heroism in compassion. The fact that Jìmūtavāhana does not lead a life of an ascetic clearly influenced Dhanika's decision against peace, as he points out that the hero maintains love for the heroin and that he receives the reward of universal sovereignty of his race in the end. ${ }^{109}$ Among those who accept that the predominant rasa of the play is that of heroism,

100 The critical edition of the Tibetan text from the fourth to sixth acts made by Roland Steiner (formerly Roland Pafeen) in his unpublished M.A. thesis submitted to the University of Bonn in 1989, Kritische Edition der Akte IV bis VI der tibetischen Übertragung von Harșadevas Schauspiel Nāgānanda, is not available to me currently. A recent reproduction of Ganapati's edition of the South Indian recension with English translation (Skilton 2009) will also be referenced.

101 (Ingalls et al. 1990, pp. 518-19). For the Sanskrit of Ānandavardhan's brief reference to the Nāgānanda, see (Masson and Patwardhan 1969, p. 94).

102 (Warder 1983, pp. 54-55). The red garments that Jīmūtavāhana receives from Malayavatī's mother allow him to disguise himself as the sacrificial victim. Moreover, the goddess Gaurī, of whom Malayavatī is a devotee, revives Jīmūtavāhana after he died from the wound inflicted by Garuda. The goddess is a Hindu element of the drama, but it can be accommodated in the framework of a Buddhist jâtaka story as it is not uncommon for a self-sacrificing bodhisattva to be rescued by a Hindu god such as Indra in these stories.

103 (Ingalls et al. 1990, pp. 518-19; Masson and Patwardhan 1969, p.94).

104 (Ingalls et al. 1990, pp. 524-25; Masson and Patwardhan 1969, pp. 94, 97).

105 Nātyaśāstra 6.79. (Krishnamoorthy 1992, vol. 1, p. 325): dānavīram dharmavīram yudhavīram tathaiva cal rasavīram api prāha brahmā trividham eva hi. (Pollock 2016, p. 53).

106 (Ingalls et al. 1990, pp. 524-25; Masson and Patwardhan 1969, pp. 94, 97).

107 (Masson and Patwardhan 1969, p. 118): tat siddham dayālakṣaṇo ity utsāho 'tra pradhānam. Translation in (ibid., p. 137). Utsāha, or enthusiasm, is the stable emotion of heroism.

108 (Gerow 1994, p. 205).

109 See (Masson and Patwardhan 1969, pp. 144-45, 148-50; Pollock 2016, p. 165; Tubb 1985, p. 148). 
opinions also differ as to whether heroism in compassion or heroism in religion should be recognized as the play's main flavor. ${ }^{110}$

In the literary history of South Asia, evidence of substantial and active Buddhist participation in the theory of rasa is hard to come by. Sa skya Pandita's (1182-1251) interpretation of nine poetic emotions is a notable exception that offers a rare Buddhist perspective on the rasa theory and may indicate a degree of reception of the theory among the Buddhist intelligentsia in the age of the community's radical decline in India. ${ }^{111}$ The Tibetan polymath's comments on nine rasas were written as a part of the Gateway to Scholarship (Mkhas pa rnams 'jug pa'i sgo), a treatise that introduces India's cultural traditions to his Tibetan compatriots. Though relatively brief, the theoretical weight of Sa pan's remarks should not be underestimated in view of the paucity of Buddhist critical comments on aestheticized emotions. It is therefore appropriate to read the Nāgānanda in light of Sa pan's rasa interpretation, ${ }^{112}$ all the more so since the Tibetan polymath has studied the play himself and cites it as an example.

Citing the esoteric Buddhist scripture Hevajratantra as a source, Sa pan admits nine rasas, including the peaceful in addition to Bharata's old list of eight rasas. ${ }^{113}$ Perhaps the most innovative aspect of Sa pan's rasa interpretation is the fact that he divides six of the nine rasas into dharma and worldly (loka) varieties, with dharma referring to the Buddhist religion (Buddha-dharma). In contrast with the approach of the earlier Indian aesthetic tradition, which reserves the peaceful for matter involving religious life, Sa pan significantly expands the scope of religious experience in the realm of aesthetics, in a move which Jonathan Gold characterizes as the "Buddhicization of rasas." 114 In the meantime, peaceful sentiment is no longer Ānandavardhana's "separate state of mind among men of greatness that is distinct from the worldly" (alokasāmānyamahānubhāvacittavrttiviśesa). ${ }^{115}$ Sa pan explains that the rasa of peace is the relinquishment of pride, vanity, and haughtiness. ${ }^{116}$ Based on this interpretation, he is unlikely to support a position that sees the peaceful as the predominant rasa in the Nāgannanda.

On the other hand, Sa pan's heroic (dpa' ba, vìra) rasa will look familiar to Indian critics. As we expect, for Sa pan heroism has dharma and worldly varieties. He says that the former class includes heroism in munificence and heroism in moral discipline, examples of the practices of bodhisattvas with which they perfect themselves (pāramitā). The worldly heroism is identified as heroism of destroying enemies in the battle. ${ }^{117}$ Sa pan has retained Bharata's old subtypes of heroism in munificence and heroism in battle. Even the innovative approach of dividing most of the emotions into dharma and worldly subtypes could have had a semantic origin in Bharata's heroism in dharma or religion. Sa pan describes the heroic as a feature of fearlessness. ${ }^{118}$

While fearlessness belongs to the character of a literary work who is a bodhisattva, the daunting tasks performed could invoke the fearful ('jigs rung, bhayannaka) sentiment, said to be "a method to make

110 See (Warder 1983, p. 56; Raghavan 1940, p. 21; Ingalls et al. 1990, pp. 525, 526n5). Whether it is possible for the peaceful to be the predominant rasa of a major work or the rasa of a drama are additional questions considered in deciding the predominant rasa of a work like Nāgānanda. See (Tubb 1985, p. 145; Masson and Patwardhan 1969, pp. 150-51; Ingalls et al. 1990, p. 525). Dhanika maintains that the peaceful cannot be the rasa of a dramatic work. See (Pollock 2016, p. 179).

111 For a short discussion of the education that Sa skya Pandita received from a team of Buddhist scholars from India, with further references, see (Gold 2008, pp. 9-14). See also (Martin 2014, pp. 590-91; Kapstein 2003, pp. 776-82).

112 The poetics section of the Mkhas pa rnams 'jug pa'i sgo is divided into a study of selected contents of Dandin's Kärvyādarśa and the author's rasa interpretation. On Sa skya Pandita's paraphrase of materials from the first and second chapters of the Kā̃yādarśa, see (Dimitrov 2002, pp. 26-31).

113 The rasa section of Sa skya Pandita's Mkhas pa rnams 'jug pa'i sgo is discussed and translated in (Gold 2008, pp. 119-30, 173-81). The Tibetan original is found in (Sa pan Kun dga' rgyal mtshan 2004, pp. 103-11). Gold has noted that Sa pan does not seem to have maintained a distinction between rasas and other emotions (bhāva). (Gold 2008, p. 120). Therefore, he does not speak of how stable and transitory emotions, reactions, and factors work together to bring out rasa.

114 (Gold 2008, pp. 119, 122-23).

115 (Masson and Patwardhan 1969, p. 94; Ingalls et al. 1990, p. 524). For Ānandavardhana, it is the peaceful rasa that is contrasted with the worldly (alokasāmānya). See also (Gold 2008, p. 129).

116 (Sa pan Kun dga' rgyal mtshan 2004, p. 106; Gold 2008, pp. 123, 176). See also (Sa pan Kun dga' rgyal mtshan 2004, p. 111; Gold 2008, pp. 128-30, 181), where a jätaka story illustrating the peaceful rasa is mentioned.

117 (Sa pan Kun dga' rgyal mtshan 2004, p. 103; Gold 2008, pp. 174, 181).

118 (Sa paṇ Kun dga' rgyal mtshan 2004, p. 103): dpa' ba ni 'jigs pa med pa'i khyad par te. (Gold 2008, p. 174). 
someone shrink back," apparently for the readers of the work. The dharma subtype of the fearful is said to be the giving of a gift and other deeds that are difficult to perform. Sa pan's further comments clarify that his primary examples are indeed jätaka tales in which selfless bodhisattvas give away parts of their body or other unusual gifts: "To illustrate with the practice of six perfections, one may use the example of Viśvamtara giving away his son and daughter; Śibi offers his eyes; Maitrībala gives the gift of his flesh; King Candraprabha gives his head; ${ }^{119}$ Suvarnavarna cuts the upper and lower parts of his body. Likewise, there are other perfections such as the moral discipline."120

Most of the examples illustrative of bodhisattvas' generosity that Sa pan cites feature the rasa of loathsome, but curiously his discussion of the repulsive does not involve instances of bodhisattvas' unusual acts of munificence. Sa pan's repulsiveness is in fact one of the three rasas that have no dharma varieties. ${ }^{121}$ It is surprising that Sa pan does not find a religious dimension in the experience of disgust, given that his name for this rasa, mi sdug pa, is recognizably a part of the well-known Buddhist term for the "contemplation on the repulsive" (mi sdug pa sgom pa). His interpretation perhaps acknowledges the affinity between disgust and fear noted earlier. Moreover, the fact that the grotesque has no role to play in some stories of the bodhisattva's incredible generosity—such as Viśvamtara's gift of his own son and daughter-may explain why fear works better as a general descriptor. ${ }^{i 22}$

There is another context where Sa pan makes further comments on the difficult deeds of bodhisattvas, and this is his discussion of what the Indian critics identify as the rasa of karuna or the tragic, which he renders as compassion (snying rje). As a key Buddhist term, compassion (taking the feminine form karuña) differs from aestheticized emotion karuna that one experiences when watching a tragedy. Jonathan Gold has already noted that the connotational shift amounts to a reconfiguration of the aesthetic experience for the Buddhist audience of literature. ${ }^{123}$ Sa pan describes here a kind of compassion that "arises upon hearing marvelous compassionate deeds of bodhisattvas," when "the mind feels unbearable, one's hair stands on end, tears flow, one is amazed, and empathy arises."124 The psychology described here is complex: there is wonder; devotion is also in the mix, indicating a more pious Buddhist response; and arguably the tragic sentiment triggered by pain is also present.

The extraordinary acts of generosity found in the jätaka tales apparently figure very significantly in Sa pan's literary references, and what he has presented in the Gateway to Scholarship in regard to these Buddhist stories indicates a multifaceted aesthetic experience. His observation is supported by the treatment of Jīmūtavāhana's sacrifice in the Nāgannanda, where it has been pointed out that the event is developed with some six different rasas. ${ }^{125}$ As he does so, Harșa is particularly skilled at presaging future events and gradually developing themes while attending to the transitions between rasas.

To focus on the sentiment that is our central concern, while Sa pan ignores repulsiveness in bodhisattva's self-sacrifice, Vidyākara finds a verse from the Nāgānanda, which he includes in the "Cremation Ground" section of the Subhāsitaratnakoṣa. The verse is a description of the surroundings spoken by the hero in the fourth act, after he has revealed his plan to save Śankacuḍa, the designated victim whom he urges to leave. It is indeed a dreadful cemetery scene.

The vultures spread a dense darkness with the flapping of their wings which have taken off, their greed increased as they snap up morsels of flesh half-fallen from their darting beaks.

119 On the story of Candraprabha, see (Kajihama 2004).

120 (Sa pan Kun dga' rgyal mtshan 2004, p. 105; Gold 2008, pp. 122-23, 175).

121 Sa pan discusses repulsiveness in (Sa pan Kun dga' rgyal mtshan 2004, p. 104; Gold 2008, p. 174). The other two rasas that are completely secular for Sa pan are the erotic and comic.

122 Gold comments on the problem of rasas that have no dharma varieties in (ibid., pp. 125-26). The Vessantara Jātaka in Pāli is more elaborate and better-known in Theravāda Buddhism and to modern readers. Sa paṇ, however, is more likely referring to the Sanskrit Viśvaṃtarajātaka (no. 9) in Āryaśūra's Jātakamālā.

123 (Gold 2008, pp. 128-29).

124 (Sa pan Kun dga' rgyal mtshan 2004, p. 105; Gold 2008, pp. 123, 175-76).

125 (Warder 1983, p. 57). Warder reports here that the commentator Śivarāma has shown that all the rasas are featured in the Nāgānanda. 
Under that dark air, streaks of flame spring from the mouths of jackals, falling with a hissing sound

on the stream of blood made smelly with a constant flow of thick fat soaking in it. ${ }^{126}$

Vidyākara's anthology highlights this verse as an early poem in Sanskrit plays on the repulsiveness of cemeteries. Like Bhavabhūti's verse which we saw earlier, Harșa's stanza also features long compounds and some harsh consonants. Critics have pointed out that the phoneme ś and conjuncts containing the phoneme $\mathrm{r}$ contribute to the loathsome sentiment. ${ }^{127}$ These sounds are used liberally in alliterative patterns here. In the Nāgannanda, the verse suggests that the grotesque is in store later in the play. An even earlier portent appears at the beginning of the fourth act where the hero and his new brother-in-law saw piles of nāga bones. ${ }^{128}$ In the fifth act, the repulsive mood continues to be developed when Śankacuḍa follows the trail of blood from Jīmūtavāhana, who is taken by the mythical bird Garuda. ${ }^{129}$ These earlier instances of the loathsome prepare the way for the hero and Garuda to emerge back on the stage. Garuḍa now speaks of having drunk Jīmūtavāhana's blood again and again and tearing the protagonist's flesh. ${ }^{130}$ The hero's courage and kind demeanor also begin to arouse Garuda's curiosity and eventually cause the lord of birds to repent.

Gary Tubb has pointed out that Indian critics turn to the Nāgannanda as a drama that exemplifies the rasa of peace, but they come to the conclusion that the predominant rasa of the play is that of heroism. ${ }^{131}$ Between these two alternatives, our discussion indicates that Sa skya Pandita would also lean toward the latter as a key emotion in the play. ${ }^{132}$ However, for Sa pan heroism joins force with a host of other sentiments that include the fearful, wonder, and tragic. The reason that some jätaka tales have chosen to give the loathsome a more visible role is that it adds a visual component to heroism and heightens it. It also facilitates the Buddhist audience's amazement at an extraordinary act of altruism.

In closing, it should be pointed out that the aesthetic experience of disgust in the representation of bodhisattvas' unusual munificence in literature cannot make full use of the model of the repulsiveness meditation. While repulsiveness merges seamlessly into a narrative of retirement from the world evoking the peaceful rasa, the question of renunciation is not essential to many jātaka tales that thematize compassionate courage; equally incidental to such narratives is the control of sexual desire. While the contemplation on the repulsive generates repulsion and turns one way from the senses, some jātaka tales feature bodhisattvas' experience of pleasure in the midst of giving of their flesh.

In the Nāgānanda, for instance, Garuda notices, "On the limb that hasn't been plucked off, one can see clearly the thrill of pleasure." 133 Langenberg suggests in this context that "the delicious experience

126 Subhāșitaratnakoṣa 1536. (Kosambi and Gokhale 1957, p. 265), with emendation in (Ingalls 1965, p. 464): cañcaccañcūddhṛtārdhacyutapisítalavagrāsasaṃṿ̛ddhagardhair gṛdhrair ārabdhapaksadvitayavidhutibhir baddhasāndrāndhakāre/ vakrodvāntāh patantyaś chim iti śikhiśikhāśrenayo 'smin śivānām asrasrotasy ajasrasrutabahalavasāvāsavisre svananti//. Cf. English translation in (Ingalls 1965, p. 400). Nägānanda 4.17 in the following Tibetan and South Indian versions: [Tibetan] (Bhattacharya 1957, p. 167); [South Indian] (Śâstrî 1917, p. 218; Skilton 2009, pp. 156, 157). Nāgānanda 4.66 in the following North Indian version: (Ghoșa et al. 1991, p. 51).

127 (Ingalls et al. 1990, pp. 390-91).

128 [Tibetan] (Bhattacharya 1957, p. 141). [South Indian] (Śâstrî 1917, pp. 193-94; Skilton 2009, pp. 138, 139). [North Indian] (Ghoșa et al. 1991, pp. 43-44).

129 [Tibetan] (Bhattacharya 1957, pp. 188-90). [South Indian] (Śâstrî 1917, pp. 243-47; Skilton 2009, pp. 176-81). [North Indian] (Ghoșa et al. 1991, p. 58).

130 [Tibetan] 6.2. (Bhattacharya 1957, pp. 203-4). [South Indian] 5.15. (Śâstrî 1917, p. 258; Skilton 2009, pp. 190, 191). [North Indian] 5.90. (Ghoșa et al. 1991, p. 62).

131 (Tubb 1985, p. 145).

132 Valor or virya is an important Buddhist term that relates to heroism in aesthetics in several ways. Valor or energetic exertion is one of the essential bodhisattva practices or perfections. Semantically, virya is the essential quality that belongs to a hero or vira. While enthusiasm or utsāha is the stable emotion of the heroic rasa, it is the concept that defines valor in Buddhism, where it is sometimes described metaphorically in militaristic terms such as putting on armor. Buddhist texts sometimes explain valor in terms of bodhisattvas' dedication to difficult practices such as giving their bodies and limbs as a gift over a long period of time. For one example of the scriptural passages that show these connections, see (Python 1973, p. 28).

133 Third line in 6.2 in the Tibetan edition, 5.15 in the South Indian editions, and 5.90 in the North Indian edition cited above. The South Indian text reads: gātram yan na viluptam eșa pulakas tatra sphuto lakṣate. Skilton's translation (p. 191) is adopted 
of a grisly death" seems to be substituted "for all the modalities of erotic desire."134 Surely this is no erotic pleasure itself, the intervention of which would be disruptive. Jīmūtavāhana's pleasure is not a regular human experience; rather, it has a theological basis in Buddhist texts that speak about the immunity to pain when advanced spiritual beings give away their body parts. ${ }^{135}$ In fact, our playwright wastes no opportunity to pit the two kinds of pleasure against each other. This he does in the moment we visited earlier where the hero compares the soft body of his new wife to the touch of the hard slaughter stone. In the space of one single verse, Harsa summarizes the gist of the play as the subordination of love to self-sacrifice, with the thrill from the sacrifice substituting for erotic pleasure. ${ }^{136}$

\section{Epilogue}

The present study shows that disgust plays different roles in two distinctive Buddhist narratives from South Asia. In the narratives of renunciation, disgust functions as a plot device contributing to a character's withdrawal from the worldly life. Disgust also accompanies the aesthetic experience of discouragement and peace as a subsidiary emotion. Such episodes of renunciation may incorporate moments of disgust with a range of elements from the contemplation on the repulsive. In the narratives of compassionate heroism, descriptions evoking revulsion are sometimes featured in grisly scenes of the heroes' gift of their own body as a way of stressing the personal cost of self-sacrifice. ${ }^{137}$ Why does disgust tend to appear in such key Buddhist moments? As the two kinds of narratives are distinct from each other, why in each case does disgust contribute to a coherent story, where its role is subsidiary? Perhaps in both kinds of narratives, repulsiveness reminds readers of the visual images of the cemetery and the idea of death, which is a heavily thematized Buddhist topic. ${ }^{138}$ When they occur, the repulsive moments enhance the emotional intensity of literary passages. For aestheticians, what guarantees the appropriateness of its deployment in the two kinds of narrative is the compatibility between disgust, on the hand, and peace or heroism that dominates the occasion, on the other. ${ }^{139}$

The present study highlights Vidyākara's Subhāṣitaratnakoṣa and Sa skya Paṇdita's Gateway to Scholarship as two instances of Buddhist engagement with the rasa theory. Perspectives gained from the two texts are applied here to examples of Sanskrit Buddhist literature with a focus on passages dealing with the loathsome, a canonized sentiment in the tradition of Indian aesthetics. Future research

here. For an additional case of the experience of pleasure while giving away a part of the body, see the Maitribalajātaka, the eighth story in Āryaśūra's Jātakamālā.

134 (Langenberg 2017, p. 87).

135 See, for instance, (De La Vallée Poussin 1907-1912, pp. 28-29).

136 Nägānanda 4.22 in the Tibetan and South Indian editions and 4.71 in the North Indian edition used and cited in this essay.

137 Corresponding to these narratives, Langenberg also sees "two typical modes of Buddhist disgust talk." For her, "[o]ne depicts the inner foulness of the sexualized female (deceptively covered over by perfumed skin), the other the grisly nature of the dying, decomposing, or mutilated body." To them, she adds a third type of Buddhist disgust text, which, exemplified by the Garbhāvakrāntisütra, is "focused on the reproductive female body and its functions." See (Langenberg 2017, p. 87). Langenberg's classification is not based on how disgust works with the predominant rasa of a narrative. She points out that in the Garbhāvakrāntisūtra the loathsome rasa also leads to the rasa of peace (ibid., p. 89).

138 The Buddhacarita may be less explicit about the use of the repulsiveness meditation as a model for the description of the sleeping girls, but verse 5.60 shows that there is tacit identification of sleep with death when it states that the maidens are "lying as if they are dead" (śayitā gatāsukalpāh). In the parallel versions in the Mahāvastu and Lalitavistara, the identification of the scene of sleeping girls with the cemetery is explicit. See (Senart 1890, p. 159; Jones 1952, p. 155; Lefmann 1977, pp. 205, 206; Foucher 2003, p. 75). See also Buddhacarita 5.65. Recall also the description of the cemetery-like environment in Nägānanda 4.17 cited above, which presages Jīmūtavāhana's self-sacrifice.

139 In addition to the Indian discussions mentioned above, Sa pan also discusses the compatibility (or the lack thereof) of different rasas in the Mkhas pa 'jug pa'i sgo. See (Sa paṇ Kun dga' rgyal mtshan 2004, pp. 106-11; Gold 2008, pp. 126-30, 176-79). Sa pan discusses emotions that are compatible and not compatible with the repulsive in (Sa pan Kun dga' rgyal mtshan 2004, pp. 106, 108; Gold 2008, pp. 177, 178). In this context, Sa pan states with supporting reasons that the erotic/passionate, tragic/compassionate, and peaceful are not compatible with the repulsive: mi sdug pa la sgeg pa dang/snying rje zhi ba'i rgyan mi sbyar/. Gold has shown that the compassionate and peaceful are two particularly important emotions for Sa pan. However, Sa pan's discussion of the peaceful is peculiar in not identifying it as the emotion associated with the pursuit of a renouncer and in considering it to be in conflict with disgust. On these two points, he disagrees with Ānandavardhana and Abhinavagupta. Sa pan's compassion also shifts from the Indian tradition's karuna as the tragic rasa. 
may reveal further substantive Buddhist forays into the theory of rasa. From Vidyākara's anthology of Sanskrit poetry and Sa skya Pandita's scholastic work, we can already catch a glimpse of the engagement with rasa among Buddhist intellectuals in the second millennium. Through their work of very different natures, the two writers offer ideas, approaches, and the potential of reading Buddhist literature in light of the rasa theory.

This study has shown that the rasa theory is clearly relevant to the Buddhist literary culture. Why, then, have Buddhists not reacted to it in a more robust manner as they did to the alamkāra theory? In the first place, Buddhist responses to Indian literary thought were slow. In the area of alamkāra studies, for instance, some three hundred years passed between the appearance of the earliest surviving alamkearaśāstra in the form of Bhāmaha's treatise and the Buddhist commentator Ratnaśrījñ̄ana's full-scale study of Danḍin's work. If Buddhism thrived in India for several more centuries, a more substantive development than what transpired might have occurred. However, Indian Buddhists from the end of the millennium were highly dedicated to the study of literature, as demonstrable from the literary activities of men such as Ratnaśrījñāna, Ratnākaraśānti, Jñānaśrīmitra, and Vidyākara. This tendency could have speeded up things. Therefore, the decline of Buddhism in India alone cannot fully explain the lack of a strong Buddhist response to the rasa theory.

A second reason that may have inhibited more active Buddhist participation is the predominantly secular makeup of emotions featured in the rasa theory, with several sentiments such as the erotic, violent (raudra), and heroism in battle being antithetical to the Buddhist doctrine. Buddhists seemed to feel more comfortable to pursue literary studies in domains such as rhetoric and metrics, which might have been perceived as neutral tools. Even while rhetorical figures are not inherently tied to any content, the erotic sample poems in works such Daṇ̣in's Käryādarśa are known to have prompted resistance from orthodox quarters of the Buddhist community and, sometimes, purified Buddhist applications of the underlying literary paradigms.

Sa skya Pandita's rasa interpretation indeed provides a recontouring of the rasa theory for the Buddhist audience. What he has performed is a survey of the spectrum to determine which rasas are amenable to deployment in Buddhist literature and to demonstrate how they can be deployed. The present study has also shown that sentiments such as the loathsome, peaceful, and heroism in compassion can unfold naturally in classical examples of Buddhist literature. Therefore, a Buddhist reworking of the mainstream rasa discourses could be achieved on the basis of selected rasas. A passage to a Buddhist rasa theory is clearly open. Sa skya Pandita's work appears to have had a dominant influence on the future course of Buddhist literary theory in Tibet. His study of a significant portion of the Kāvyādarśa inspired the transmission of that text in Tibet. Nevertheless, Tibetans would not go on to translate any other independent alamkāraśāstra. Should his rasa study in the Mkhas pa rnams 'jug $p a^{\prime} i$ sgo be keyed to a specific theoretical text, the fate of the rasa theory in Tibet might have been different. The fact that he did not do so, however, may also tell us something about the state of rasa studies among Buddhist intellectuals from India.

Funding: This research received no external funding.

Acknowledgments: The author wishes to acknowledge the support from the Major Program of National Social Science Foundation of China (Grant No. 17ZDA235).

Conflicts of Interest: The author declares no conflict of interest.

\section{References}

Bhattacharya, Vidhushekhara, ed. 1957. Nāgānanda: Edited with Introduction and Notes. Calcutta: The Asiatic Society.

Bosch, Frederik David Kan. 1914. De legende van Jīmūtavāhana in de sanskrit-litteratuur. Leiden: Van Doesburgh. Chalmers, Robert, ed. 1994. The Majjhima-nikāya. Oxford: Pali Text Society, vol. 3.

De La Vallée Poussin, Louis, ed. 1907-1912. Madhyamakāvatāra par Candrakīrti: Traduction tibétaine. St. Petersburg: Académie Impériale des Sciences. 
Dharmachakra Translation Committee, trans. 2013. 'Phags pa rgya cher rol pa zhes bya ba theg pa chen po'i mdo: The Noble Great Vehicle Sūtra "The Play in Full"; Āryalalitavistaranāmamahāyānasūtra, Current version v 4.47.1 (2020). Available online: https://read.84000.co/translation/toh95.html (accessed on 21 July 2020).

Dimitrov, Dragomir. 2002. Mārgavibhāga: Die Unterscheidung der Stilarten: Krtische Ausgabe der Ersten Kapitels von Dandins Poetik Kāvyādarśa und der tibetischen Übertragung Sñān ṅag me lon் nebst einer deutschen Übersetzung des Sanskrittextes. Indica et Tibetica, Bd. 40. Marburg: Indica et Tibetica Verlag.

Dimitrov, Dragomir. 2011. Śabdālaṃkāradoṣavibhāga: Die Unterscheidung der Lautfiguren und der Fehler. Wiesbaden: Harrassowitz, 2 vols.

Foucher, Alfred. 2003. The Life of the Buddha: According to the Ancient Texts and Monuments of India. Translated into English by Simone Brangier Boss. New Delhi: Munshiram Manoharlal.

Gerow, Edwin. 1994. Abhinavagupta's Aesthetics as a Speculative Paradigm. Journal of the American Oriental Society 114: 186-208. [CrossRef]

Ghoṣa, Mādhava Candra, Krṣna Kamala Bhațāāārya, Michael Hahn, and Roland Steiner. 1991. The Recensions of the Nāgānanda by Harșadeva. Vol. 1: The North Indian Recension. New Delhi: Aditya Prakashan.

Gold, Jonathan C. 2008. The Dharma's Gatekeepers: Sakya Pandita on Buddhist Scholarship in Tibet. Albany: State University of New York Press.

Goldman, Robert P. 2000. Rāvaṇa's Kitchen: A Testimony of Desire and the Other. In Questioning Rāmāyaṇa. Edited by Paula Richman. Delhi: Oxford University Press, Berkeley and Los Angeles: University of California Press, pp. 105-16.

Graulund, Rune. 2019. Grotesque. Oxford Research Encyclopedia of Literature. Online Publication Date: October. Available online: https:/oxfordre.com/literature/view/10.1093/acrefore/9780190201098.001.0001/acrefore9780190201098-e-1067 (accessed on 14 September 2020).

Gray, Louis H., ed. and trans. 1962. Vāsavadattā: A Sanskrit Romance by Subandhu. Delhi: Motilal Banarsidass.

Hahn, Michael. 1970. Ist ein Vers der Nāndī in Harṣadevas Drama Nāgānanda verloren gegangen? Wiener Zeitschrift für die Kunde Süd-und Ostasiens 14: 39-45.

Hall, Fitzedward, ed. 1859. The Vásavadattá: A Romance. Bibliotheca Indica 30. Calcutta: Asiatic Society of Bengal.

$\mathrm{He}, \mathrm{Xi}$. 2012. Experiencing the Graceful and the Joyful: A Study of the Literary Aesthetics and Religious Emotions of the Lalitavistara. Ph.D. dissertation, University of Chicago, Chicago, IL, USA.

Hiltebeitel, Alf. 2006. Aśvaghoșa's 'Buddhacarita': The First Known Close and Critical Reading of the Brahmanical Sanskrit Epics. Journal of Indian Philosophy 36: 229-86. [CrossRef]

Ingalls, Daniel H. H. 1965. An Anthology of Sanskrit Court Poetry; Vidyākara's "Subhāṣitaratnakoṣa". Harvard Oriental Series 44. Cambridge: Harvard University Press.

Daniel H. H. Ingalls, Jeffrey Moussaieff Masson, and M. V. Patwardhan, transs. 1990, The Dhvanyāloka of Ānandavardhana with the Locana of Abhinavagupta. Harvard Oriental Series 49. Cambridge: Harvard University Press.

Johnston, Edward Hamiltonand, ed. and trans. 1975. The Saundarananda of Aśvaghoṣa. Delhi: Motilal Banarsidass.

Johnston, Edward Hamiltonand, ed. and trans. 1998. Aśvaghoṣa's Buddhacarita or Acts of the Buddha. 3 parts. Delhi: Motilal Banarsidass.

Jones, J. J., trans. 1952, The Mahāvastu. London: Luzac, vol. 2.

Kajihama, Ryōshun. 2004. The Story of the King Candraprabha in the 'Sa skya legs bshad' Commentary. Journal of Indian and Buddhist Studies 53: 453-58. [CrossRef]

Kapstein, Matthew T. 2003. The Indian Literary Identity in Tibet. In Literary Cultures in History: Reconstructions from South Asia. Edited by Sheldon Pollock. Berkeley: University of California Press, pp. 747-802.

Khams sprul Bstan 'dzin chos kyi nyi ma. 1986. Rgyan gyi bstan bcos dbyangs can ngag gi rol mtsho. Lhasa: Bod ljongs mi dmangs dpe skrun khang.

Khoroche, Peter, trans. 1989, Once the Buddha Was a Monkey: Āryaśūra's Jātakamālā. Chicago: University of Chicago Press.

Kosambi, Damodar Dharmanand, and Vasudeo Vishwanath Gokhale, eds. 1957. The Subhāṣitaratnakoṣa. Harvard Oriental Series 42; Cambridge: Harvard University Press.

Krishnamoorthy, Keralapura, ed. 1992. Nātyaśāstra of Bharatamuni: With the Commentary Abhinavabhāratī by Abhinavaguptācārya, 4th ed. Vadodara: Oriental Institute.

Lamotte, Étienne. 1988. History of Indian Buddhism: From the Origin to the Śaka Era. Translated from French by Sara Webb-Boin. Louvain: Peeters Press. 
Langenberg, Amy Paris. 2017. Birth in Buddhism: The Suffering Fetus and Female Freedom. Routledge Critical Studies in Buddhism. London: Routledge.

Lefmann, Salomon, ed. 1977. Lalita Vistara: Leben und Lehre des Çākya-Buddha. Erster Teil: Text. Halle, A.S.: Buchhandlung des Waisenhauses. Reprint Tokyo: Meicho-fukyū-kai. First published 1902.

Martin, Dan. 2014. Indian Kāvya Poetry on the Far Side of the Himālayas: Translation, Transmission, Adaptation, Originality. In Innovations and Turning Points: Toward a History of Kāvya Literature. Edited by Yigal Bronner, David Shulman and Gary Tubb. Oxford: Oxford University Press, pp. 563-608.

Masson, Jeffrey Moussaieff, and Madhav Vinayak Patwardhan. 1969. Śāntarasa and Abhinavagupta's Philosophy of Aesthetics. Poona: Bhandarkar Oriental Research Institute.

Nānamoli, Bhikkhu, trans. 2010, The Path of Purification (Visuddhimagga) by Bhadantācariya Buddhaghosa. Colombo: Buddhist Publication Society.

Bhikkhu Ñānamoli, and Bhikkhu Bodhi, transs. 2005, The Middle Length Discourses of the Buddha: A Translation of the Majjhima Nikâya. Somerville: Wisdom Publications.

Olivelle, Patrick, trans. 2008, Life of the Buddha by Aśvaghoṣa. New York: New York University Press.

Pollock, Sheldon. 2016. A Rasa Reader: Classical Indian Aesthetics. New York: Columbia University Press.

Pradhan, Prahlad, ed. 1967. Abhidharm-koshabhāsya of Vasubandhu. Patna: K. P. Jayaswal Research Institute.

Python, Pierre. 1973. Vinaya-viniścaya-upāli-paripṛcchā: Enquête d'Upāli pour une exégèse de la discipline. Paris: A. Maisonneuve.

Raghavan, Venkatarama. 1940. The Number of Rasas. Madras: Adyar Library.

Rhys Davids, Caroline Augusta Foley, ed. 1975. The Visuddhi-magga of Buddhaghosa. Distributed by Routledge \& Kegan Paul. London: The Pali Text Society.

Sa pạ Kun dga' rgyal mtshan. 2004. Mkhas pa rnams 'jug pa'i sgo. In Zlos gar dang mkhas 'jug. Beijing: Mi rigs dpe skrun khang, pp. 83-196.

Sâstrî, T. Ganapati, ed. 1917. The Nâgânanda of Srî Harsha Deva: With the Commentary Nâgânandavimarsinî by Sivarâma. Trivandrum: Government Press.

Sathaye, Adheesh. 2010. The Production of Unpleasurable Rasas in the Sanskrit Dramas of Ārya Kṣemīśvara. Journal of the American Oriental Society 130: 361-84.

Senart, Émile, ed. 1890. Le Mahāvastu: Text sanscrit publié pour la première fois et accompagné d'introductions et d'un commentaire. Tome Deuxième. Paris: Imprimerie nationale.

Shukla, Karunesha, ed. 1973. Śrāvakabhūmi of Ācārya Asanga. Patna: K. P. Jayaswal Research Institute.

Singh, Mann. 1993. Subandhu. New Delhi: Sahitya Akademi.

Skilton, Andrew. 2009. "How the Nāgas Were Pleased" by Harșa E "The Shattered Thighs" by Bhāsa. New York: New York University Press.

Steiner, Roland. 1997. Untersuchungen zu Harșadevas Nāgānanda und zum indischen Schauspiel. Indica et Tibetica Bd. 31. Swisttal-Odendorf: Indica et Tibetica-Verlag.

Strong, John S. 2008. The Legend of King Aśoka: A Study and Translation of the Aśokāvadāna. Delhi: Motilal Banarsidass.

Takakusu, Junjirō, and Kaigyoku Watanabe, eds. 1924-1932. Taishō shinshū Daizōkyō. Tokyo: Taishō Issaikyō Kankōkai, 85 vols.

Thakur, Anantalal, and Upendra Jha, eds. 1957. Kāvyalakṣaṇa of Dandin (Also Known as Kāoyādarśa): With Commentary Called Ratnaśrī of Ratnaśrījñāna. Darbhanga: Mithila Institute of Post-Graduate Studies and Research in Sanskrit Learning.

Tubb, Gary A. 1985. Śāntarasa in the Mahābhārata. Journal of South Asian Literature 20: 141-68.

Tzohar, Roy. 2019. Reading Aśvaghoṣa Across Boundaries: An Introduction. Journal of Indian Philosophy 47: 187-94. [CrossRef]

Ui, Hakuju, Munetada Suzuki, Enshō Kanakura, and Tōkan Tada. 1934. A Complete Catalogue of the Tibetan Buddhist Canons: (Bhah-hgyur and Bstan-hgyur). Sendai: Tohoku Imperial University Aided by the Saito Gratitude Foundation.

Vaidya, Parashuram Lakshman, ed. 1999a. Divyāvadāna. Darbhanga: The Mithila Institute of Post-Graduate Studies and Research in Sanskrit Learning.

Vaidya, Parashuram Lakshman, ed. 1999b. Jātaka-mālā by Āryaśūra. Darbhanga: The Mithila Institute of Post-Graduate Studies and Research in Sanskrit Learning.

Warder, Anthony Kennedy. 1983. Indian Kāvya Literature. Volume IV: The Way of Originality (Bāna to Dāmodaragupta). Delhi: Motilal Banarsidass. 
Wilson, Liz. 1996. Charming Cadavers: Horrific Figuration of the Feminine in Indian Buddhist Hagiographic Literature. Chicago: University of Chicago Press.

Zhang, Yuan. 2018. 戒日王研究: A comprehensive study on Harsavardhana, or Śīlāditya, 590-647 AD. Beijing: Shehuikexue Wenxian Chubanshe.

(c)

(C) 2020 by the author. Licensee MDPI, Basel, Switzerland. This article is an open access article distributed under the terms and conditions of the Creative Commons Attribution (CC BY) license (http://creativecommons.org/licenses/by/4.0/). 